ARTICLE

https://doi.org/10.1038/s41467-019-13565-9

\title{
NAIL-MS reveals the repair of 2-methylthiocytidine by AlkB in E. coli
}

Valentin F. Reichle ${ }^{1}$, Dimitar P. Petrov ${ }^{2}$, Verena Weber ${ }^{1}$, Kirsten Jung ${ }^{2}$ \& Stefanie Kellner (D) ${ }^{1 \star}$

RNAs contain post-transcriptional modifications, which fulfill a variety of functions in translation, secondary structure stabilization and cellular stress survival. Here, 2methylthiocytidine $\left(\mathrm{ms}^{2} \mathrm{C}\right)$ is identified in tRNA of $E$. coli and $P$. aeruginosa using NAIL-MS (nucleic acid isotope labeling coupled mass spectrometry) in combination with genetic screening experiments. $\mathrm{ms}^{2} \mathrm{C}$ is only found in 2-thiocytidine $\left(\mathrm{s}^{2} \mathrm{C}\right)$ containing tRNAs, namely tRNA ${ }^{{ }^{A r g}}{ }_{C C G}$ tRNA ${ }^{A r g}{ }_{I C G}$, tRNA ${ }^{A r g}{ }_{U C U}$ and tRNA ${ }^{\text {Ser }}{ }_{G C U}$ at low abundances. $\mathrm{ms}^{2} \mathrm{C}$ is not formed by commonly known tRNA methyltransferases. Instead, we observe its formation in vitro and in vivo during exposure to methylating agents. More than half of the $\mathrm{s}^{2} \mathrm{C}$ containing tRNA can be methylated to carry $\mathrm{ms}^{2} \mathrm{C}$. With a pulse-chase NAIL-MS experiment, the repair mechanism by AlkB dependent sulfur demethylation is demonstrated in vivo. Overall, we describe $\mathrm{ms}^{2} \mathrm{C}$ as a bacterial tRNA modification and damage product. Its repair by AlkB and other pathways is demonstrated in vivo by our powerful NAIL-MS approach.

\footnotetext{
${ }^{1}$ Department of Chemistry, Ludwig-Maximilians-University Munich, Butenandtstr. 5-13, 81377 Munich, Germany. ${ }^{2}$ Department of Biology, LudwigMaximilians-University Munich, Grosshaderner Str. 2-4, 82152 Martinsried, Germany. *email: stefanie.kellner@cup.uni-muenchen.de
} 
E ach Nucleic acid is composed of four canonical nucleobases, which are connected through ribose (RNA) or 2'-O-deoxyribose (DNA) and phosphate. In addition, both DNA and RNA are target of modifying enzymes which introduce methylations or other functionalities. To this day, over 160 modified nucleosides have been identified in RNA from organisms in all domains of life ${ }^{1}$.

Due to the nucleophilic character of the canonical nucleobases, both RNA and DNA are prone to direct methylation. Inside cells these electrophiles comprise molecules such as Sadenosylmethionine (SAM), which is the common methyldonor for enzymatic methylation reactions but it is also known to directly alkylate nucleic acids ${ }^{2}$. In addition, bacteria use various electrophiles as chemical warheads (e.g., streptozotocin, azaserine or methylenchloride) to harm other bacteria by methylation and alkylation of their macromolecules ${ }^{3-6}$. Thus, bacteria are constantly forced to overcome these alkylating reagents and various adaptive mechanisms can be found. To study the impact of direct methylation, electrophiles such as methyl-methanesulfonate (MMS) or dimethyl sulfate (DMS) are used. Methylation damage of both RNA and DNA is repaired by direct demethylation through the alpha-ketoglutarate dependent dioxygenase $\mathrm{AlkB}$ in bacteria ${ }^{7,8}$. So far the methylated aromatic nitrogens of 3methylcytidine $\left(\mathrm{m}^{3} \mathrm{C}\right)$, 1-methyladenosine $\left(\mathrm{m}^{1} \mathrm{~A}\right)$ and 1methylguanosine $\left(\mathrm{m}^{1} \mathrm{G}\right)$ are reported substrates of AlkB. In addition, the exocyclic amines of N2,N2-dimethylguanosine $\left(\mathrm{m}^{2,2} \mathrm{G}\right)$ can be demethylated by AlkB in vitro, which finds application in the RNA modification sequencing technique ARMSeq $^{9}$. So far, no non-nitrogen methylations have been described as substrates of AlkB in RNA.

In addition to the nucleobase methylations introduced by direct alkylation, cells in all domains of life use SAM for the enzymatic methylation of RNA. The occurrence of these natural methylated nucleosides makes the detection of damage-derived methylated nucleosides challenging. With the application of $\mathrm{CD}_{3}$ labeled methionine in a nucleic acid isotope labeling coupled mass spectrometry (NAIL-MS) assay, this discrimination can be achieved and, e.g., enzymatic 7-methylguanosine $\left(\mathrm{m}^{7} \mathrm{G}\right)$ and MMS-damage derived $\mathrm{m}^{7} \mathrm{G}$ can be quantified independently ${ }^{10}$. With NAIL-MS, the analysis of alkylation damage of canonical nucleosides was possible in the presence of natural methylated nucleosides. A key finding in this study was that $\mathrm{m}^{7} \mathrm{G}$ damage is as common as $\mathrm{m}^{1} \mathrm{~A}$, which was believed to be the only dominant RNA damage product upon direct methylation in vivo ${ }^{11}$. In addition, NAIL-MS was used in a pulse-chase setup to follow the in vivo demethylation kinetics of $\mathrm{m}^{1} \mathrm{~A}$ and $\mathrm{m}^{3} \mathrm{C}$ during $\mathrm{MMS}$ recovery ${ }^{10}$. Especially $\mathrm{m}^{3} \mathrm{C}$ is quickly and efficiently $(\sim 80 \%)$ repaired within nine hours of recovery whereas only $20 \%$ of $\mathrm{m}^{1} \mathrm{~A}$ damage sites are repaired within the same timeframe ${ }^{12}$. For $\mathrm{m}^{3} \mathrm{C}$, the demethylation by $\mathrm{AlkB}$ is reported in vitro, but so far not in vivo ${ }^{13}$.

While methylation is a major modification of RNA, especially tRNA contains additional and more complex modifications. One group of unique tRNA modifications is the enzymatic thiolation. For example, bacteria thiolate cytidine at position 32 of the tRNA to form 2-thiocytidine $\left(\mathrm{s}^{2} \mathrm{C}\right)$. The thiolated nucleosides at position 32 and 37 of tRNA flank the anticodon (position 34-36) allowing for a more flexible anticodon loop and thus improve the binding of the codon during translation. $\mathrm{s}^{2} \mathrm{C}$ is incorporated into bacterial

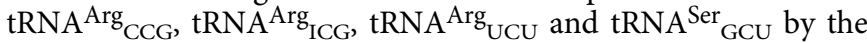
thiotransferase TtcA at position 32. Its effects on tRNA structure and bacterial translation has been addressed in several studies 14,15

Here, through the use of genetic and analytical tools, we identify and confirm the structure of 2-methylthiocytidine as an endogenous modification in bacterial tRNA. In accordance with the nomenclature provided by the RNA community ${ }^{1}$ it is abbreviated as $\mathrm{ms}^{2} \mathrm{C}$. The new modification is present in the same tRNA isoacceptors as its precursor modification $s^{2} \mathrm{C}$, but only $1 \%$ of all $s^{2} \mathrm{C}$ modified tRNAs are methylated to $\mathrm{ms}^{2} \mathrm{C}$. Due to the low abundance of $\mathrm{ms}^{2} \mathrm{C}$ in vivo and its formation by SAM in vitro, $\mathrm{ms}^{2} \mathrm{C}$ might present an endogenous tRNA lesion. During exposure of bacteria to the natural antibiotic streptozotocin and the alkylating reagent MMS, up to $50 \%$ of the $s^{2} \mathrm{C}$ modified tRNAs become methylated and $\mathrm{ms}^{2} \mathrm{C}$ is formed. Thus, $\mathrm{ms}^{2} \mathrm{C}$ is an additional damage product of bacterial RNA and of comparable abundance to the main methylation products $\mathrm{m}^{1} \mathrm{~A}$ and $\mathrm{m}^{7} \mathrm{G}$ in tRNA $^{10,11}$. With our unique NAIL-MS approach, we observe a fast and efficient repair of $\mathrm{ms}^{2} \mathrm{C}$ and regeneration of $\mathrm{s}^{2} \mathrm{C}$ in the damaged tRNAs. With NAIL-MS, we identify high demethylation activity of $\mathrm{AlkB}$ towards $\mathrm{ms}^{2} \mathrm{C}$ and $\mathrm{m}^{3} \mathrm{C}$, and only slow demethylation of the described substrate $\mathrm{m}^{1} \mathrm{~A}$. In addition, we observe $s^{2} \mathrm{C}$ from rethiolated cytidine after dethiomethylation by an AlkB independent mechanism. Overall, NAIL-MS is a tool which is useful for the identification of nucleoside structures and allows deeper insights into RNA demethylation mechanisms in vivo.

\section{Results}

2-methylthiocytidine is a bacterial tRNA modification. With the goal of discovering novel modified nucleosides in bacterial tRNA, Escherichia coli and Pseudomonas aeruginosa were grown in differentially stable isotope labeled growth media as recently reported ${ }^{16,17}$. The total tRNA were purified and analyzed by mass spectrometry. After data evaluation we found a promising candidate eluting at $5.2 \mathrm{~min}$ with an $\mathrm{m} / \mathrm{z}$ of 274 from unlabeled tRNA, an $\mathrm{m} / \mathrm{z}$ of 284 from $\left[{ }^{13} \mathrm{C}\right]$-labeled tRNA, an $\mathrm{m} / \mathrm{z}$ of 277 from $\left[{ }^{15} \mathrm{~N}\right]$-labeled tRNA and an $m / z$ of 276 from $\left[{ }^{34} \mathrm{~S}\right]$-labeled tRNA (Fig. 1a, Supplementary Table 1). The sum formula of the nucleobase is $\mathrm{C}_{5} \mathrm{H}_{x} \mathrm{~N}_{3} \mathrm{O}_{y} \mathrm{~S}_{1}$ (Supplementary Fig. 1) and the nucleoside is thus $\mathrm{C}_{10} \mathrm{H}_{X} \mathrm{~N}_{3} \mathrm{O}_{X} \mathrm{~S}_{1}$. Through the addition of the heavy labeled amino acid $\mathrm{CD}_{3}$-methionine to the growth medium, we predicted the presence of a single methyl-group in the nucleoside candidate. Aiming at clarification of the analyte's structure, we screened E. coli knockouts for its absence. TtcA is responsible for 2-thiolation of cytidine and in the $\Delta t t c A$ strain, the $\mathrm{m} / z 274$ signal is lost alongside 2-thiocytidine $\left(\mathrm{s}^{2} \mathrm{C}\right.$ ) (Supplementary Fig. 2a, Supplementary Tables 2 and 3) ${ }^{18}$. The mass difference of the novel nucleoside $(\mathrm{m} / z 274)$ and $\mathrm{s}^{2} \mathrm{C}(\mathrm{m} / z 260)$ is 14 Dalton, which is a strong indicator of methylation of $\mathrm{s}^{2} \mathrm{C}$.

Due to the high nucleophilicity of thiols, we predicted that both the chemical synthesis and biosynthesis of 2-methylthiocytidine $\left(\mathrm{ms}^{2} \mathrm{C}\right)$ is feasible, and thus the methylation reaction at position 2 of $s^{2} \mathrm{C}$ was performed. Interestingly, the synthetic route was already described in 2010, when the Suzuki lab ${ }^{19}$ used 2methylthiocytidine as an intermediate of agmatidine synthesis. We followed their synthetic route under milder conditions and received pure $\mathrm{ms}^{2} \mathrm{C}$ in $28 \%$ yield (Supplementary Figs. $2 \mathrm{~b}$ and 3 ). We mixed the synthesized $\mathrm{ms}^{2} \mathrm{C}$ with the heavy isotope labeled tRNA digests and observed perfect co-elution for the synthesized compound and its native isotopologues (Fig. 1a). Additional high resolution $\mathrm{MS}, \mathrm{MS}^{2}$ and $\mathrm{MS}^{3}$ spectra of the synthesized product and of native tRNA confirmed the structure of the novel nucleoside to be $\mathrm{ms}^{2} \mathrm{C}$ in $E$. coli (Fig. 1b) and P. aeruginosa (Supplementary Fig. 4).

With the synthetic standard of $\mathrm{ms}^{2} \mathrm{C}$ and an internal standard produced by metabolic isotope labeling ${ }^{20}$, we could now quantify the absolute abundance of $\mathrm{ms}^{2} \mathrm{C}$ in specific tRNAs from the unstressed E. coli BW25113 wild-type strain (WT). The precursor of $\mathrm{ms}^{2} \mathrm{C}, \mathrm{s}^{2} \mathrm{C}$ is reported in three of the five tRNA ${ }^{\mathrm{Arg}}$ isoacceptors and one of the five tRNA $^{\text {Ser }}$ isoacceptors ${ }^{1,14,21}$. Therefore, we designed DNA probes (Supplementary Table 4) against tRNAs 
a
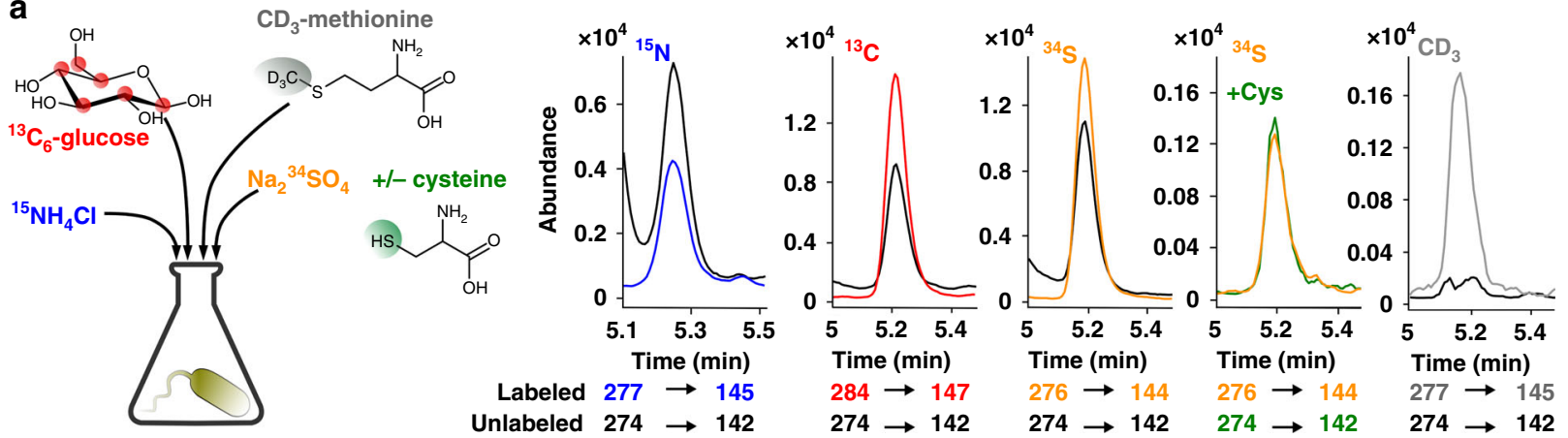

b

Synthetic

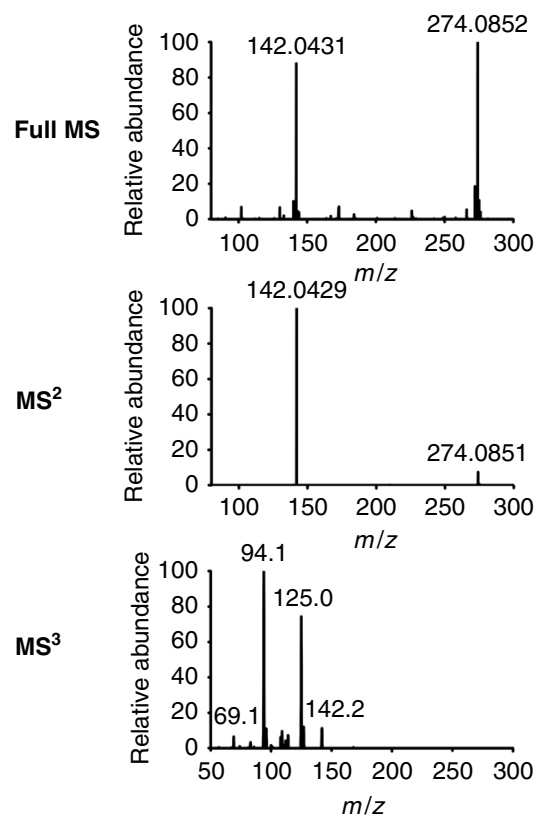

Digest
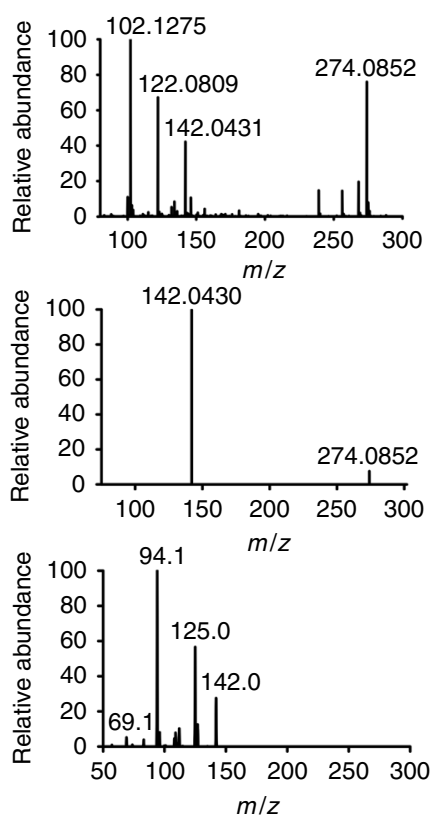

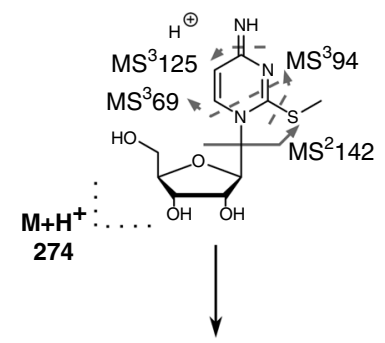

$\oplus_{\mathrm{NH}_{2}}$<smiles>CSc1nc(=N)cc[nH]1</smiles>

$m / z: 142$

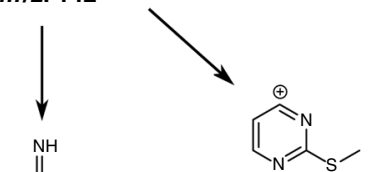

$m / z: 125$

C
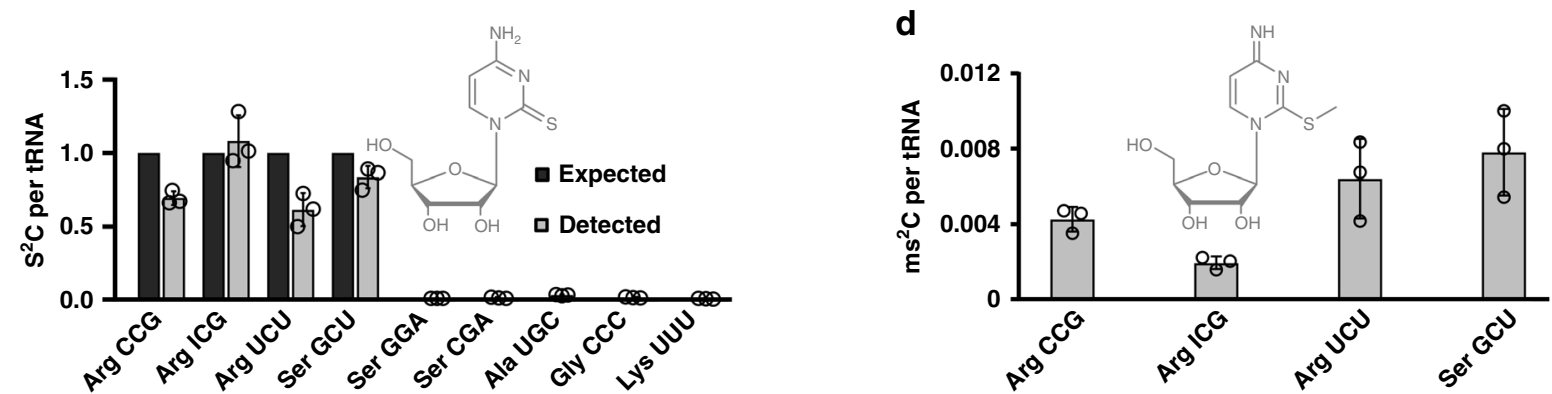

Fig. 1 Verification of 2-methylthiocytidine $\left(\mathbf{m s}^{\mathbf{2}} \mathbf{C}\right)$ structure and distribution in bacterial tRNA isoacceptors. a Different isotope labeling in bacteria. Coelution of the synthesized $\mathrm{ms}^{2} \mathrm{C}$ nucleoside (black) and $\mathrm{ms}^{2} \mathrm{C}$ from $\left.\left[{ }^{15} \mathrm{~N}\right],{ }^{13} \mathrm{C}\right]$ or $\left[{ }^{34} \mathrm{~S}\right]$ labeled bacteria and products of metabolic labeling with $\left[{ }^{32} \mathrm{~S}\right]-$ cysteine in $\left.{ }^{34} \mathrm{~S}\right]$ medium and $\mathrm{CD}_{3}$-methionine labeling. The respective isotope is indicated above each chromatogram. $\mathbf{b}$ High resolution mass spectrometry and fragmentation of $\mathrm{ms}^{2} \mathrm{C}$ by direct injection of the synthetic standard or the natural bacterial digest and collision induced dissociation. c Expected (black) $)^{1}$ and experimentally detected (gray) abundance of $\mathrm{s}^{2} \mathrm{C}$ per respective tRNA isoacceptor. $\mathbf{d}$ Experimentally detected abundance of ms ${ }^{2} \mathrm{C}$ per respective $\mathrm{s}^{2} \mathrm{C}$ containing tRNA isoacceptor. All experiments are from $n=3$ biol. replicates, error bars reflect standard deviation. Source data of (c) and (d) are provided as a Source Data file.

with a reported $s^{2} \mathrm{C}$, namely tRNA ${ }^{A r g}{ }_{\mathrm{CCG}}, \mathrm{tRNA}^{\mathrm{Arg}}{ }_{\mathrm{ICG}}, \mathrm{tRNA}{ }^{\mathrm{Ar}-}$ $\mathrm{g}_{\mathrm{UCU}}$ and $\mathrm{tRNA}^{\mathrm{Ser}}{ }_{\mathrm{GCU}}$, and purified these isoacceptor tRNAs from total tRNA ${ }^{22}$. As a control we decided to isolate tRNAs with C32 (tRNA ${ }_{\text {Ser }}{ }_{\text {GGA }}$, tRNA Lys ${ }_{U U U}$ ), a tRNA with 2'-O-methylcy-

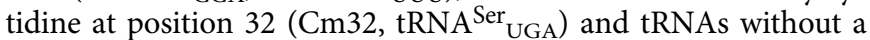
$\mathrm{C} 32$, tRNA ${ }^{\text {Gly }}{ }_{\mathrm{CCC}}$ and tRNA ${ }^{\mathrm{Ala}}{ }_{\mathrm{UGC}}$. As expected, we found $\mathrm{s}^{2} \mathrm{C}$ in
tRNA ${ }^{A r g}{ }_{C C G}, \quad t_{R N A} \operatorname{Arg}_{\text {ICG }}, \quad$ tRNA $^{A r g}{ }_{U C U}$ and tRNA $^{\text {Ser }}{ }_{G C U}$ (Fig. 1c). The complete modification profile of these tRNAs is shown in Supplementary Table 5 and Supplementary Fig. $5 . \mathrm{ms}^{2} \mathrm{C}$ was also found in these $\mathrm{s}^{2} \mathrm{C}$-containing tRNA isoacceptors, however according to our data only $0.2-1.0 \%$ of actually $\mathrm{s}^{2} \mathrm{C}$ modified tRNAs contain $\mathrm{ms}^{2} \mathrm{C}$. 
For exploration of the biosynthetic pathway, we quantified the abundance of $\mathrm{ms}^{2} \mathrm{C}$ in total tRNA from the E. coli WT and various isogenic knockout strains (Supplementary Table 2) in glucose-containing M9 minimal medium (Supplementary Fig. 6) and LB medium (Supplementary Fig. 7). In total tRNA from WT E. coli grown in $\mathrm{M} 9$ we found $0.08 \mathrm{~s}^{2} \mathrm{C}$ per average tRNA, and only $\sim 0.00032 \mathrm{~ms}^{2} \mathrm{C}$. In the $\Delta t t c A$ mutant no ${ }^{2} \mathrm{C}$ and $\mathrm{ms}^{2} \mathrm{C}$ were detectable (corresponding to less than 0.00005 modifications per tRNA). We observed decreased $\mathrm{ms}^{2} \mathrm{C}$ formation in various knockout strains grown in M9 medium but not in LB medium. To exclude an involvement of these enzymes in $\mathrm{ms}^{2} \mathrm{C}$ formation, we analyzed $E$. coli strains that overexpress tRNA modifying enzymes (Supplementary Fig. 7 and Supplementary Table 6). This confirmed that none of the investigated enzymes is involved in $\mathrm{ms}^{2} \mathrm{C}$ biosynthesis. The overall low abundance and high fluctuation of $\mathrm{ms}^{2} \mathrm{C}$ in unstressed bacteria hints towards its nature as an endogenous tRNA lesion. Indeed, in vitro experiments showed the formation of $\mathrm{ms}^{2} \mathrm{C}$ from $\mathrm{s}^{2} \mathrm{C}$ in the presence of SAM and MMS (Supplementary Fig. 8).

2-thiocytidine is a main substrate of MMS alkylation in vivo. Intrigued by the possibility that $s^{2} \mathrm{C}$ is methylated in vivo by naturally occurring methyl donors like SAM, we were wondering about its methylation during alkylation stress. We exposed WT E. coli to the $\mathrm{LD}_{50}$ dose of MMS (20 mM), non-lethal MMS doses (3 $\mathrm{mM}$ and $0.5 \mathrm{mM}$ ) and the $\mathrm{LD}_{50}$ dose of the natural antibiotic streptozotocin (STZ, $200 \mu \mathrm{M}$ ) in M9 medium (Supplementary Fig. 9). The total tRNA was isolated for absolute quantification by LC-MS/MS (Supplementary Table 7). The results for the main RNA damage product $\mathrm{m}^{1} \mathrm{~A}$ and $\mathrm{ms}^{2} \mathrm{C}$ are shown in Fig. 2a. We observed $\sim 0.1 \mathrm{~m}^{1} \mathrm{~A}$ per tRNA and $\sim 0.05 \mathrm{~ms}^{2} \mathrm{C}$ per tRNA in the $20 \mathrm{mM}$ MMS exposed bacteria. With the non-lethal dose of $3 \mathrm{mM}$ MMS, the formation of damage is reduced to $0.014 \mathrm{~m}^{1} \mathrm{~A}$ and $0.018 \mathrm{~ms}^{2} \mathrm{C}$ per tRNA. With low doses of alkylating agent, the $\mathrm{s}^{2} \mathrm{C}$ damage was more prominent in total tRNA than the adenosine damage. The absolute abundance of other modified nucleosides is shown in Supplementary Figs. 10 and 11. STZ methylated both adenosine $\left(0.03 \mathrm{~m}^{1} \mathrm{~A} / \mathrm{tRNA}\right)$ and $\mathrm{s}^{2} \mathrm{C}\left(0.008 \mathrm{~ms}^{2} \mathrm{C} / \mathrm{tRNA}\right)$. Overall, $\mathrm{ms}^{2} \mathrm{C}$ formed readily during alkylation stress and in comparable extent to $\mathrm{m}^{1} \mathrm{~A}$.

While $\mathrm{m}^{1} \mathrm{~A}$ is known to be a direct methylation product, the increase in $\mathrm{ms}^{2} \mathrm{C}$ might be caused by either direct methylation or SAM-derived enzymatic methylation. To elucidate the origin of the methylation in $\mathrm{ms}^{2} \mathrm{C}$ under MMS stress, we used nucleic acid isotope labeling coupled mass spectrometry (NAIL-MS) to discriminate direct and SAM-derived methylation during MMS stress in vivo. Adapted from our recently established assay ${ }^{10}$, we cultured E. coli WT bacteria in the presence of $\mathrm{CD}_{3}$-methionine to allow complete $\mathrm{CD}_{3}$-labeling of all SAM dependent methylated nucleosides. One aliquot of these bacteria was exposed to the $\mathrm{LD}_{50}$ dose of MMS, while the other remained unstressed. After 1 $\mathrm{h}$ of MMS exposure the tRNA was purified and analyzed by LCMS/MS. Enzymatically methylated nucleosides carry a +3 label whereas the directly MMS methylated nucleosides are unlabeled and thus the two species are distinguishable by mass spectrometry. Absolute quantification of the enzymatically and directly methylated nucleosides in the unstressed and stressed cells revealed the abundance of methylated nucleosides in the samples. The fold changes between the stressed and unstressed samples were calculated and plotted in Fig. $2 \mathrm{~b}$. We observed only little adaptation of enzymatically introduced tRNA modifications under these growth conditions. The strongest increase was 1.7 fold, observed for Um (2'-O-methyluridine) from total tRNA. In both the stressed and unstressed samples, $\mathrm{ms}^{2} \mathrm{C}$ was again found to be labeled through $\mathrm{CD}_{3}$-methionine dependent pathways, with a slightly higher abundance in the stressed samples. This small increase in $\mathrm{CD}_{3}$-methylated $\mathrm{ms}^{2} \mathrm{C}$ does not reflect its substantial abundance in Fig. 2a. In contrast to the SAM dependent methylations, we found a high increase for the known products of direct methylation, namely $\mathrm{m}^{3} \mathrm{U}$ ( 5 fold), $\mathrm{m}^{6} \mathrm{~A}$ ( 47 fold), $\mathrm{m}^{7} \mathrm{G}$ (64 fold) $\mathrm{m}^{1} \mathrm{~A}$ (64 fold) and $\mathrm{m}^{3} \mathrm{C}$ (74 fold) ${ }^{10}$. However, the highest increase was for the product of direct $\mathrm{s}^{2} \mathrm{C}$ methylation, $\mathrm{ms}^{2} \mathrm{C}$, which was over 500 fold increased in the stressed bacteria compared to the unstressed (absolute quantities in Supplementary Fig. 12). Thus, we prove that the $\mathrm{ms}^{2} \mathrm{C}$ observed in Fig. $2 \mathrm{a}$ originated from direct $\mathrm{s}^{2} \mathrm{C}$ methylation by MMS.

The previous experiments were done with total tRNA, but only four tRNA isoacceptors carry $\mathrm{s}^{2} \mathrm{C}$. To study the impact of direct methylation on these $s^{2} \mathrm{C}$-containing tRNAs, we performed a comparative NAIL-MS experiment. For this purpose, the unstressed $E$. coli are grown in ${ }^{13} \mathrm{C}_{6}$-glucose labeled medium and the MMS exposed bacteria $\left(\mathrm{LD}_{50}\right)$ in unlabeled medium. After cell harvesting, the unstressed and stressed bacteria were mixed to avoid purification biases, as recently suggested ${ }^{12}$. From the resulting co-purified total tRNA, the tRNA isoacceptors SerGCU, ArgCCG, ArgICG and Arg ${ }^{\mathrm{UCU}}$ were isolated, digested and subjected to LC-MS/MS analysis. The mass spectrometer was set to distinguish the ${ }^{13} \mathrm{C}$-labeled nucleosides (unstressed bacteria) from the unlabeled nucleosides (stressed bacteria) and thus the abundance of each nucleoside can be determined (Supplementary Figs. 13 and 14, Supplementary Tables 8 and 9). On average, we found $0.8 \mathrm{~s}^{2} \mathrm{C}$ per respective unstressed tRNA, but after MMS exposure, the abundance of $s^{2} \mathrm{C}$ drops substantially (Fig. 2c, left). For tRNA SerGCU, ArgCCG and $\mathrm{Arg}^{\mathrm{UCU}}$ we found a 4 -fold decrease to $<0.2 \mathrm{~s}^{2} \mathrm{C}$ per tRNA. tRNA ${ }^{A r g}$ ICG $_{\text {was }}$ the only exception with a $\sim 2$-fold decrease to around $0.4 \mathrm{~s}^{2} \mathrm{C}$ per tRNA. As expected, the abundance of $\mathrm{ms}^{2} \mathrm{C}$ was increased in the stressed samples, which indicated that the lost $\mathrm{s}^{2} \mathrm{C}$ was directly methylated to $\mathrm{ms}^{2} \mathrm{C}$ in these tRNAs (Fig. $2 \mathrm{c}$, middle). In all purified tRNAs, the $\mathrm{ms}^{2} \mathrm{C}$ abundance was higher than the $\mathrm{m}^{1} \mathrm{~A}$ abundance (Fig. 2c, right).

This data demonstrates that $\mathrm{s}^{2} \mathrm{C}$ is a better substrate of the methylation agent MMS than adenosine.

2-methylthiocytidine may influence translation. The $s^{2} \mathrm{C}$ containing tRNAs are major targets of direct methylation by MMS. $\mathrm{s}^{2} \mathrm{C}$ is located at position 32 where it fulfils important roles in translation of the serine codons $\mathrm{AGU}$ and $\mathrm{AGC}$ by $\mathrm{tRNA}^{\mathrm{Ser}}{ }_{\mathrm{GCU}}$ and the arginine codons CGG (tRNA ${ }^{A r g}{ }_{\mathrm{CCG}}$ ), AGA (tRNA ${ }^{\mathrm{Ar}}$ $\left.\mathrm{g}_{\mathrm{UCU}}\right)$ and CGC, CGU and CGA (tRNA $\left.{ }^{\mathrm{Arg}_{\mathrm{ICG}}}\right)^{14}$. The methylation of $s^{2} \mathrm{C}$ and formation of $\mathrm{ms}^{2} \mathrm{C}$ might result in electronic and electrostatic shifts of the nucleobase, which potentially changes the properties of the whole anticodon loop of the affected tRNAs. Thus translation of the respective serine and arginine codons might be influenced by the methylation of $s^{2} \mathrm{C}$. To address this question, the effect of MMS on the synthesis of superfolder green fluorescent protein (sfGFP) in E. coli WT was determined. We decided to study sfGFP (for sequence and used primers see Supplementary Table 10), which contains one AGC (at position 2) and one AGT codon for serine, five GCU, two CGC and one CGG codon for arginine. 10 codons are translated by s ${ }^{2} \mathrm{C}$ modified tRNAs, which will be damaged to carry $\mathrm{ms}^{2} \mathrm{C}$ under MMS stress. Thus the translation of sfGFP could be effected by MMS due to the $s^{2} \mathrm{C}$ methylation. Expression of $s f g f p$ was under control of the $\mathrm{P}_{\mathrm{BAD}}$ promoter, and unstressed or stressed (exposures to $20 \mathrm{mM}$ MMS for $1 \mathrm{~h}$ ) cells of the mid-log growth phase were induced by arabinose. Fluorescence intensity of single $E$. coli cells of strain BW25113 was determined after 1 and $5 \mathrm{~h}$ (Supplementary Fig. 15). In the presence of $3 \mathrm{mM}$ MMS, fluorescence was significantly lower under acute stress $(1 \mathrm{~h})$, but cells 
a

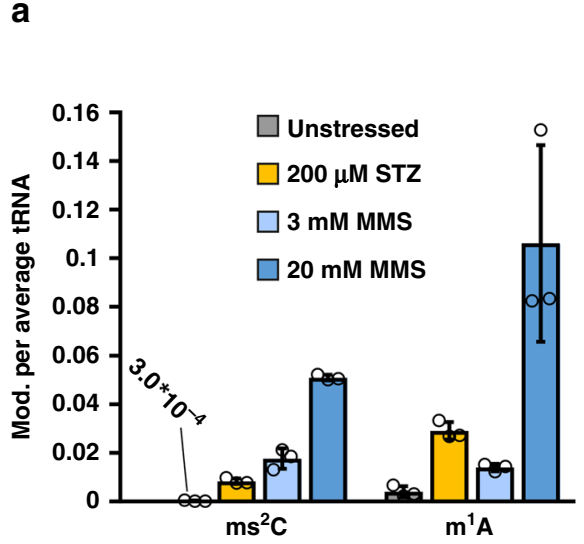

b

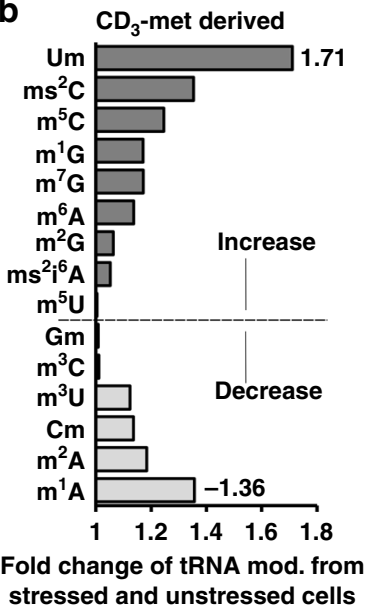

MMS derived

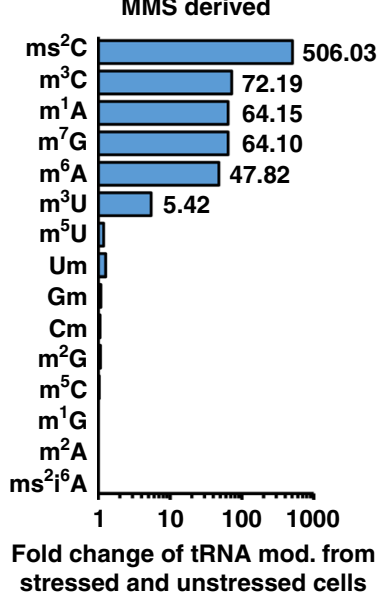

C

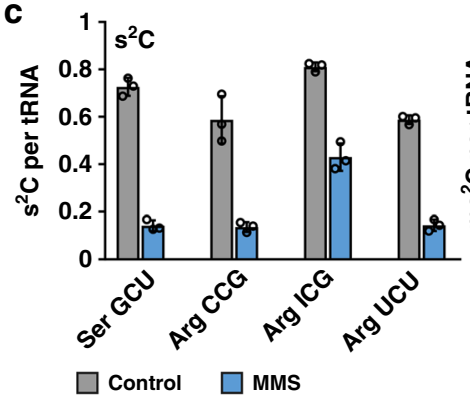

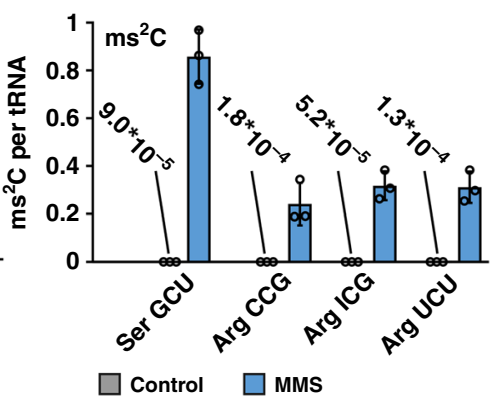

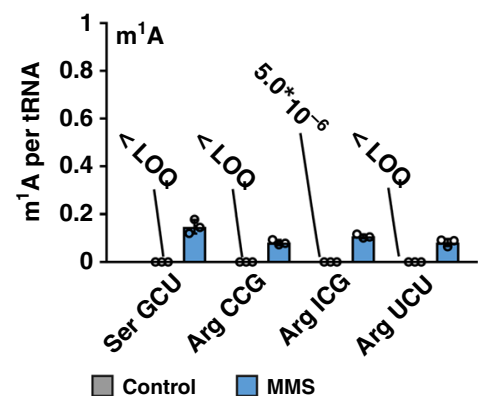

Fig. 2 Absolute abundance of modified nucleosides in total tRNA and tRNA isoacceptors after methylation stress. a Abundance of mod. (ms ${ }^{2} \mathrm{C}$ and $\mathrm{m}^{1} \mathrm{~A}$ ) per average tRNA after $0 \mathrm{mM}$ (unstressed, gray), $200 \mu \mathrm{M}$ Streptozotocin (STZ, natural methylating agent, $50 \%$ lethality, orange), $3 \mathrm{mM}$ MMS (no lethality, light blue) and $20 \mathrm{mM}$ MMS (50\% lethality, dark blue). b Impact of MMS exposure (unstressed vs. $20 \mathrm{mM}$ stressed) on E. coli total tRNA modifications (mod.). The origin of the methylated tRNA modifications is displayed in separate plots. Left: impact of $\mathrm{MMS}$ exposure on $\mathrm{CD}_{3}$-met (met $=$ methionine) derived methylation displayed as the fold change ratio of stressed-to-unstressed. Right: impact of MMS exposure on directly methylated nucleosides (MMS derived methylation) displayed as the fold change of stressed-to-unstressed. c Absolute abundance of $\mathrm{s}^{2} \mathrm{C}$ (left), ms ${ }^{2} \mathrm{C}$ (middle) and $\mathrm{m}^{1} \mathrm{~A}$ (right) in various tRNA isoacceptors without (gray) and with (blue) $20 \mathrm{mM} \mathrm{MMS} \mathrm{exposure.} \mathrm{In} \mathrm{the} \mathrm{negative} \mathrm{control} \mathrm{(without} \mathrm{MMS)} \mathrm{E.} \mathrm{coli} \mathrm{were} \mathrm{grown}$ in ${ }^{13} \mathrm{C}$ medium (gray bars, control) and the MMS exposed bacteria in non-labeled (blue bars, MMS) media. Co-purification of tRNA isoacceptors was done in a comparative NAIL-MS experiment as detailed in the text. All experiments are from $n=3$ biol. replicates and error bars reflect standard deviation. Source data are provided as a Source Data file.

recovered after $5 \mathrm{~h}$ indicated by the increase in fluorescence. Similar results are seen for cells after exposure to $20 \mathrm{mM} \mathrm{MMS}$ (Fig. 3a). We mutated a single codon in the sfgfp gene to replace the AGC codon for serine with AGT and TCC (Fig. 3b). While AGC and AGT are read by the same $s^{2} \mathrm{C}$ modified tRNA ${ }^{\text {Ser }}{ }_{\text {GCU, }}$, the TCC codon is read by tRNA ${ }^{\mathrm{Ser}}{ }_{\mathrm{GGA}}$, which is not $\mathrm{s}^{2} \mathrm{C}$ modified and thus the anticodon is not affected by the MMS stress (see Fig. 1c). We tested the influence of these codons (AGC, AGT, TTC) at position 2 in sfGFP on the fluorescence in the WT strain. Fluorescence of stressed cells producing the AGT- and AGCvariants of sfGFP is more affected in comparison to the TCC construct (Fig. 3c). At the used MMS doses, we previously observed about $80 \% \mathrm{~ms}^{2} \mathrm{C}$ modified tRNA SerGCU while only $20 \%$ were $\mathrm{s}^{2} \mathrm{C}$ modified (Fig. 2c). Thus we see a direct correlation of $\mathrm{ms}^{2} \mathrm{C}$ abundance and decreased translational efficiency for the respective codons. Moreover, translation of the AGT-containing sfGFP was slightly more affected by the methylating agent than the AGC-containing construct. These results indicate a negative effect of $\mathrm{ms}^{2} \mathrm{C}$ on translation.

2-methylthiocytidine is efficiently repaired by AlkB. The $\mathrm{ms}^{2} \mathrm{C}$ damage has a potential effect on the translation of $E$. coli. It is highly probable that the methylation damage is recognized and repaired by the bacteria to adapt to the stress. This repair is either possible by direct demethylation by AlkB as shown for $\mathrm{m}^{1} \mathrm{~A}^{23}$ or by tRNA degradation. To address the question whether $\mathrm{ms}^{2} \mathrm{C}$ is repaired and which mechanism dominates, we designed a pulsechase assay involving stable isotope labeling. Figure $4 \mathrm{a}$ shows the principle of the assay. The goal of this assay is to discriminate the damaged tRNAs from the tRNAs transcribed during the recovery. Thus, we can follow the fate of the damaged tRNAs and their nucleosides independently from dilution by transcription. For this purpose, cells were grown in media containing only $\left[{ }^{14} \mathrm{~N}\right]$ and $\left.{ }^{32} \mathrm{~S}\right]$-nutrients. Consequently, the RNA was completely labeled with $\left[{ }^{14} \mathrm{~N}\right]$ and all $s^{2} \mathrm{C}$ have a $\left[{ }^{32} \mathrm{~S}\right]$ label (original $\mathrm{s}^{2} \mathrm{C}$ ), e.g. $m / z\left(\mathrm{~s}^{2} \mathrm{C}\right)$ 260. All methylated nucleosides had a $\mathrm{CH}_{3}$ mark (e.g., original $\mathrm{m}^{1} \mathrm{~A} \mathrm{~m} / z$ 282). In this medium, the cells were exposed to MMS $\left(\mathrm{LD}_{50}\right)$ and $\mathrm{s}^{2} \mathrm{C}$ was converted to $\mathrm{ms}^{2} \mathrm{C}$ and, e.g., $\mathrm{A}$ to $\mathrm{m}^{1} \mathrm{~A}$. After exposure, MMS was removed by exchanging the media with heavy-isotope media. During the following recovery period, newly transcribed RNA were $\left[{ }^{15} \mathrm{~N}\right]$ labeled, newly methylated nucleosides were $[\mathrm{CD}]_{3}$ labeled and new $\mathrm{s}^{2} \mathrm{C}$ had a $\left[{ }^{34} \mathrm{~S}\right]$ label (new s ${ }^{2} \mathrm{C}$, $m / z 265$ and new $\mathrm{m}^{1} \mathrm{~A}, m / z 290$ ).

The dashed line in Fig. $4 \mathrm{~b}$, represents the decrease of $\mathrm{m}^{1} \mathrm{~A}$ if referenced to the sum of all tRNAs (original + new transcripts). The fast decrease is caused by dilution due to ongoing tRNA transcription. In the past, this decrease could be misinterpreted as active tRNA demethylation, but with NAIL-MS we can follow the fate of modified nucleosides inside living cells by excluding 
a

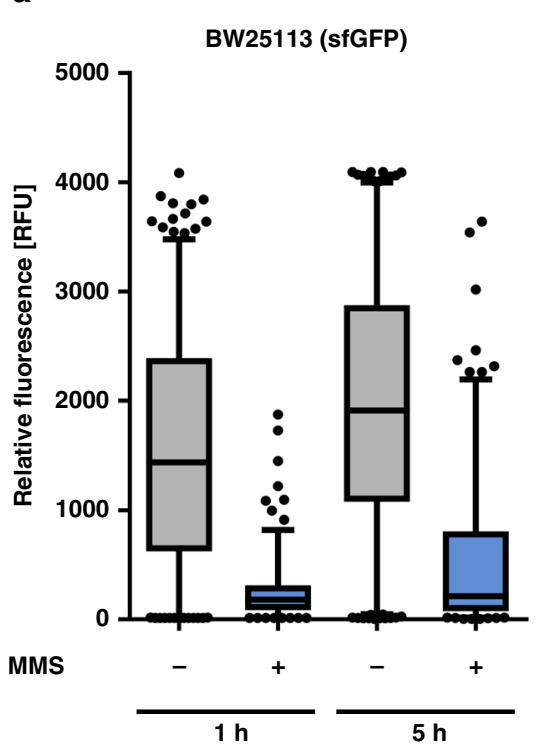

b

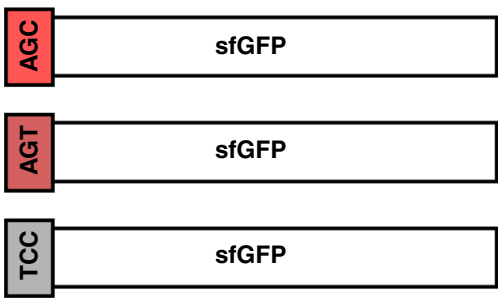

C

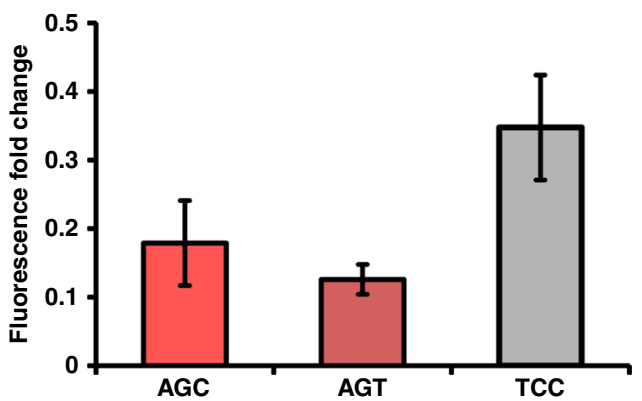

Fig. 3 Impact of $\mathbf{s}^{\mathbf{2}} \mathbf{C}$ methylation on translation. a Long-term effects of $20 \mathrm{mM}$ MMS stress on sfGFP synthesis in E. coli WT cells. Single cell fluorescence was determined for a minimum of $300 \mathrm{E}$. coli cells producing sfGFP under control of the L-arabinose inducible promoter (pBAD24). Fluorescence was measured 1 and $5 \mathrm{~h}$ after addition of arabinose to unstressed cells or cells pre-exposed to $20 \mathrm{mM} \mathrm{MMS}$ stress for $1 \mathrm{~h}$. (box plots represent the 5 -95\% percentile) $\mathbf{b}$ Illustration of the used sfGFP constructs. The serine on amino acid position 2 of the used sfGFP variant was encoded by different codons: AGC, AGT and TCC. $\mathbf{c}$ Influence of codons on sfGFP synthesis after exposure of cells to MMS stress. Fluorescence was measured after $1 \mathrm{~h}$ of induction with arabinose. The fold change was determined by dividing the mean fluorescence of stressed cells (20 mM MMS) by the mean fluorescence of unstressed cells. All experiments are from $n=3$ biol. replicates and error bars reflect standard deviation. Source data are provided as a Source Data file.

transcription processes. By referencing $\mathrm{m}^{1} \mathrm{~A}$ abundance to the original tRNAs, we saw a slow but steady decrease of $\mathrm{m}^{1} \mathrm{~A}$ in the damaged tRNAs over time which reflects true demethylation (Fig. 4b, solid line). For $\mathrm{ms}^{2} \mathrm{C}$, we saw a fast and nearly complete repair over the same observation period (Fig. 4b). This decrease was not caused by increased tRNA degradation as MMS exposed bacteria showed the same original-tRNA dilution pattern as unstressed bacteria (Supplementary Fig. 16). We isolated tRNAs SerGCU and ArgICG from the NAIL-MS pulse-chase experiments, and for these damaged tRNAs we saw no increased degradation either (Supplementary Fig. 17). Thus we conclude that the removal of $\mathrm{ms}^{2} \mathrm{C}$ from damaged tRNA is not caused by tRNA degradation.

$\mathrm{m}^{1} \mathrm{~A}$ is known to be demethylated by $\mathrm{AlkB}^{13,23}$. To test whether $\mathrm{AlkB}$ also demethylates $\mathrm{ms}^{2} \mathrm{C}$ to $\mathrm{s}^{2} \mathrm{C}$, we isolated total tRNA from MMS exposed bacteria and tested the AlkB activity in vitro. After addition of AlkB to the damaged tRNA, we could no longer detect $\mathrm{ms}^{2} \mathrm{C}$ and $\mathrm{m}^{1} \mathrm{~A}$ in the tRNA (Fig. 4c). Instead, we could observe an increase of $s^{2} \mathrm{C}$, which indicates that $\mathrm{AlkB}$ demethylates $m s^{2} \mathrm{C}$ to $s^{2} \mathrm{C}$. This finding is rather surprising as, until now, only nitrogen demethylation was observed for AlkB but never sulfur demethylation ${ }^{11,23}$.

To verify that $\mathrm{AlkB}$ demethylates $\mathrm{ms}^{2} \mathrm{C}$ containing tRNAs in vivo, we decided to repeat the NAIL-MS pulse-chase assay in an alkB deficient $E$. coli strain. After exposure to $20 \mathrm{mM}$ MMS, we observed a fast decrease of $\mathrm{ms}^{2} \mathrm{C}$ in the WT strain and a slower decrease in the isogenic $\triangle a l k B$ mutant (Fig. 4d). Interestingly, we observed an increase of $\mathrm{s}^{2} \mathrm{C}$ in the WT strain but not in the $\triangle$ alkB strain (Fig. 4e). Our data indicates that a portion of $\mathrm{ms}^{2} \mathrm{C}$ is demethylated by AlkB under recovery of the original $\left[{ }^{32} \mathrm{~S}\right]-\mathrm{s}^{2} \mathrm{C}$. The other portion of $\mathrm{ms}^{2} \mathrm{C}$ seems to be lost by an $\mathrm{AlkB}$ independent mechanism. For $\mathrm{m}^{3} \mathrm{C}$ we also observed an $\mathrm{AlkB}$ dependent demethylation, but surprisingly not for $\mathrm{m}^{1} \mathrm{~A}$ (Supplementary Fig. 18). We repeated the experiment in the presence of $3 \mathrm{mM}$ MMS and $0.5 \mathrm{mM}$ MMS to ensure the viability of the cells.
$3 \mathrm{mM}$ MMS corresponds to $20 \%$ lethality in the $\triangle a l k B$ strain (Supplementary Fig. 19) and no lethality in the WT strain. Directly after $3 \mathrm{mM}$ MMS exposure, the abundance of $\mathrm{ms}^{2} \mathrm{C}, \mathrm{m}^{1} \mathrm{~A}$ and $\mathrm{m}^{3} \mathrm{C}$ per original tRNA was comparable in the WT and $\triangle a l k B$ strain (Supplementary Fig. 20). After $2 \mathrm{~h}$ of recovery, the abundance of $\mathrm{ms}^{2} \mathrm{C}, \mathrm{m}^{1} \mathrm{~A}$ and $\mathrm{m}^{3} \mathrm{C}$ was more reduced in the WT strain compared to the $\triangle a l k B$ mutant. This indicates repair of $\mathrm{ms}^{2} \mathrm{C}$ by AlkB in vivo as observed in Fig. $4 \mathrm{~d}$. For $0.5 \mathrm{mM}$ MMS, we saw an $\mathrm{AlkB}$ independent reduction of $\mathrm{m}^{1} \mathrm{~A}, \mathrm{~m}^{3} \mathrm{C}$, and $\mathrm{ms}^{2} \mathrm{C}$ of comparable extent. On tRNAs with a damage abundance below a threshold level, AlkB appeared to be uninvolved in repair.

In summary, we demonstrate that $\mathrm{ms}^{2} \mathrm{C}$ damaged $\mathrm{tRNAs}$ are yet undescribed substrates of $\mathrm{AlkB}$, both in vitro and in vivo.

Dethiomethylation as an alternative repair pathway. The in vitro as well as the in vivo analyses of $A l k B$ convinced us of the role of $\mathrm{AlkB}$ as key player in $\mathrm{ms}^{2} \mathrm{C}$ demethylation. Based on our data shown in Fig. 4, we assume direct demethylation by AlkB, which results in the recovery of $\left[{ }^{32} \mathrm{~S}\right]-\mathrm{s}^{2} \mathrm{C}$.

Chemically, the thiomethyl group is an acceptable leaving group in the presence of nucleophiles such as water. Dethiomethylation might occur inside the cell and would result in the formation of canonical cytidine. In theory, this cytidine should then be a substrate of TtcA and a rethiolation to $\mathrm{s}^{2} \mathrm{C}$ would result (Fig. 5a). Such an $s^{2} \mathrm{C}$ turnover event is observable in vivo with our pulse-chase NAIL-MS experiment. During the design of the experiment, we chose two media with different sulfur isotopes. The stress medium contains the sulfur-32 isotope and thus all $\mathrm{s}^{2} \mathrm{C}$ of original tRNAs is $\left[{ }^{32} \mathrm{~S}\right]-\mathrm{s}^{2} \mathrm{C}$ with an $\mathrm{m} / z$ of 260 . The recovery medium contains no sulfur-32, but sulfur- 34 instead. Thus, $\mathrm{s}^{2} \mathrm{C}$ in new transcripts is not only three units heavier (nitrogen-15) but five units $\left(\left[{ }^{15} \mathrm{~N}_{3} /{ }^{34} \mathrm{~S}\right]-\mathrm{s}^{2} \mathrm{C}, \mathrm{m} / z 265\right)$. In case of the imagined scenario of spontaneous dethiomethylation of $\mathrm{ms}^{2} \mathrm{C}$ into cytidine followed by rethiolation into $s^{2} \mathrm{C}$, only sulfur-34 is available and 
a
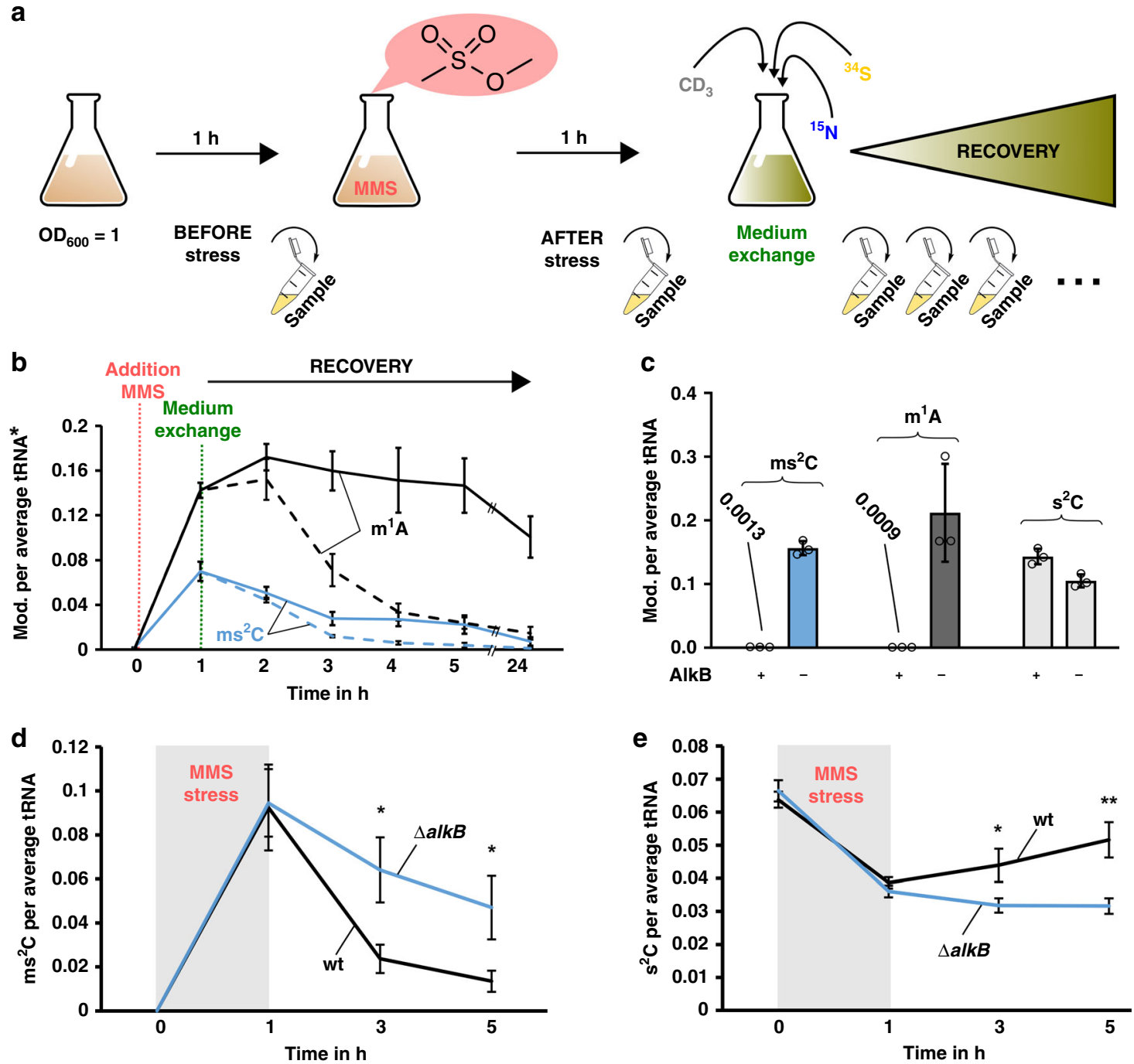

Fig. 4 Principle and results of pulse-chase NAIL-MS experiments to determine the repair of $\mathbf{m s}^{\mathbf{2}} \mathbf{C}$ in vivo. a Principle of a pulse-chase NAIL-MS experiment. The bacteria are grown in unlabeled (n.l.) media before and after exposure to MMS (structure shown). After $1 \mathrm{~h}$ MMS exposure, the media is removed and fresh, $\left.\left[{ }^{15} \mathrm{~N}\right],{ }^{34} \mathrm{~S}\right]$ and $\left[\mathrm{CD}_{3}\right]$-methionine containing media is added. Samples are drawn during the recovery time for tRNA isolation. b Formation of the nucleoside damage product $\mathrm{ms}^{2} \mathrm{C}$ (blue) and $\mathrm{m}^{1} \mathrm{~A}$ (black) per average tRNA after $20 \mathrm{mM}$ MMS exposure. ${ }^{*}$ Dashed lines: abundance of mod. ( $m s^{2} \mathrm{C}$ and $\mathrm{m}^{1} \mathrm{~A}$ ) per all tRNAs (sum of original, unlabeled and new, $\left[{ }^{15} \mathrm{~N}\right]$-labeled transcripts). Solid lines: abundance of mod. (ms ${ }^{2} \mathrm{C}$ and $\mathrm{m}^{1} \mathrm{~A}$ ) per original tRNA. c Abundance of mod. ( $\mathrm{ms}^{2} \mathrm{C}$ in blue, $\mathrm{m}^{1} \mathrm{~A}$ in dark gray and $\mathrm{s}^{2} \mathrm{C}$ in light gray) per tRNA incubated with purified AlkB in vitro. The substrate

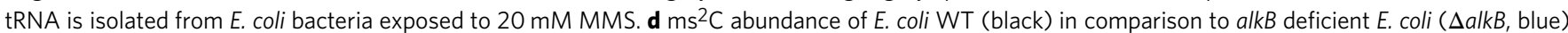
after MMS stress $\left(20 \mathrm{mM}, 1 \mathrm{~h}\right.$ ) and during recovery in a pulse-chase NAIL-MS experiment, as described in a) and b). e $\mathrm{s}^{2} \mathrm{C}$ abundance of $E$. coli WT (black) in comparison to alkB deficient $E$. coli ( $\triangle$ alkB, blue) after MMS stress $(20 \mathrm{mM}, 1 \mathrm{~h})$ and during recovery. All experiments are from $\mathrm{n}=3$ biol. replicates and error bars reflect standard deviation. $p$-values from student t-test (equal distribution, two-sided): ${ }^{\star} p<0.05$ and ${ }^{\star \star} p<0.01$. Source data are provided as a Source Data file.

thus the original $\left[{ }^{32} \mathrm{~S}\right]-\mathrm{s}^{2} \mathrm{C}$ would turn into $\left[{ }^{34} \mathrm{~S}\right]-\mathrm{s}^{2} \mathrm{C}$ with an $\mathrm{m} / \mathrm{z}$ of 262 . The original $\left[{ }^{32} \mathrm{~S}\right]-\mathrm{s}^{2} \mathrm{C}$ produced by AlkB demethylation and the hypothetical turnover $\left[{ }^{34} \mathrm{~S}\right]-\mathrm{s}^{2} \mathrm{C}$ formed after dethiomethylation/rethiolation can be distinguished by mass spectrometry (Supplementary Table 11).

The result for the unstressed and $20 \mathrm{mM}$ MMS treated WT strain is shown in Fig. 5b. Immediately after the stress, the number of turnover $\left[{ }^{34} \mathrm{~S}\right]-\mathrm{s}^{2} \mathrm{C}$ was comparable and rose over time. The increase of $\left[{ }^{34} \mathrm{~S}\right]-\mathrm{s}^{2} \mathrm{C}$ in unstressed bacteria was most likely caused by regular $\mathrm{s}^{2} \mathrm{C}$ biosynthesis into original tRNAs, which were not fully mature at the time of medium exchange. The presence of only $\left[{ }^{34} \mathrm{~S}\right]$ at these later time points led to the formation of $\left.{ }^{34} \mathrm{~S}\right]-\mathrm{s}^{2} \mathrm{C}$ in the control bacteria. In contrast, MMS exposure led to more $\left[{ }^{34} \mathrm{~S}\right]-\mathrm{s}^{2} \mathrm{C}$. To test involvement of AlkB in the formation of turnover $\left[{ }^{34} \mathrm{~S}\right]-\mathrm{s}^{2} \mathrm{C}$, we plotted the $\left[{ }^{34} \mathrm{~S}\right]-\mathrm{s}^{2} \mathrm{C}$ abundance observed in the $\triangle a l k B$ strain (Fig. $5 c$ ). Here, we saw an increase in turnover $\mathrm{s}^{2} \mathrm{C}$, which was comparable to the turnover in the WT strain. We thus conclude that the turnover is not a consequence of the AlkB repair process.

The increase in turnover $\mathrm{s}^{2} \mathrm{C}$ can be explained by dethiomethylation of $\mathrm{ms}^{2} \mathrm{C}$ followed by rethiolation of the formed cytidine. Currently it is unclear, whether the dethiomethylation occurs spontaneously after a nucleophilic attack of water or by an enzymatic pathway. From a chemical perspective, we believe that spontaneous dethiomethylation is the most likely.

\section{Discussion}

In this study, we identified $\mathrm{s}^{2} \mathrm{C}$ as a substrate of direct methylation in bacterial tRNAs, and the mechanisms of the subsequent 
a

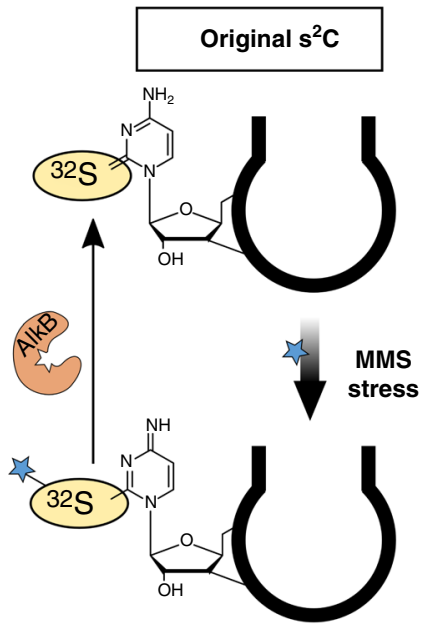

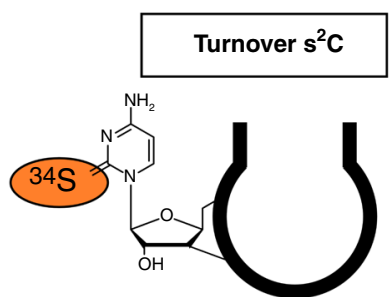

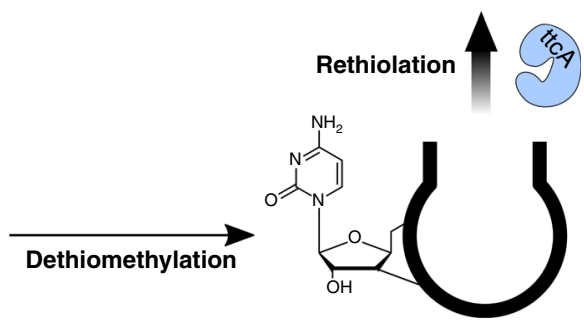

b
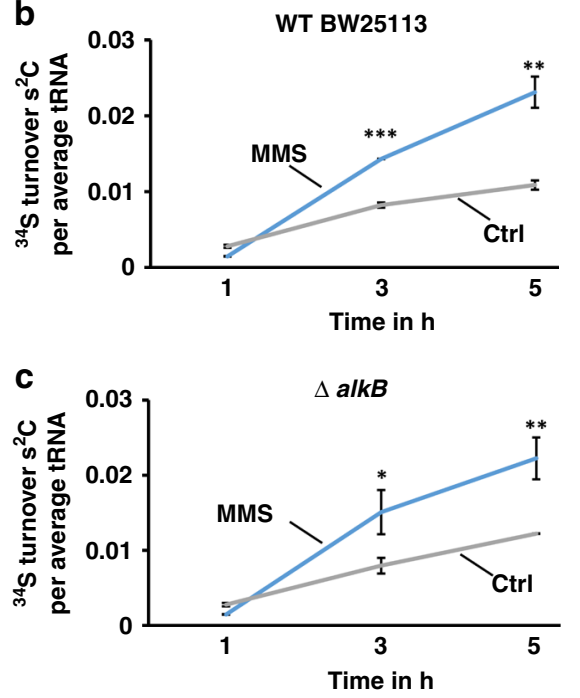

Fig. 5 Pulse-chase NAIL-MS analysis of turnover $\mathrm{s}^{\mathbf{2} C}$ after $20 \mathrm{mM}$ MMS exposure in WT BW25113 and E. coli $\Delta$ alkB knockout strain. a Concept of turnover $\mathrm{s}^{2} \mathrm{C}$ generation and its detection by NAIL-MS. b Abundance of $\left.{ }^{34} \mathrm{~S}\right]$ turnover $\mathrm{s}^{2} \mathrm{C}$ in WT BW25113 during recovery after MMS stress (20 mM) and unstressed control. c Abundance of $\left.{ }^{34} \mathrm{~S}\right]$ turnover $\mathrm{s}^{2} \mathrm{C}$ in the $\Delta$ alkB strain during recovery after MMS stress $(20 \mathrm{mM})$ and unstressed control. All experiments are from $n=3$ biol. replicates and error bars reflect standard deviation. $p$-values from student t-test (equal distribution, two-sided): ${ }^{\star} p<0.05$, ${ }^{\star \star} p<0.01$ and ${ }^{\star \star *} p<0.001$. Source data are provided as a Source Data file.

repair by AlkB. We initially identified the new structure of the methylated nucleoside in total tRNA of $E$. coli and $P$. aeruginosa. The structure of the $\mathrm{ms}^{2} \mathrm{C}$ (2-methylthiocytidine) nucleoside was confirmed after synthesis by various analytical tools including fragmentation patterns in high resolution mass spectrometry. Methylated derivatives of other thiolated nucleosides like $s^{4} U$ or $m n m^{5} s^{2} U$ might also form endogenously, but were not detected in our nucleoside discovery experiments.

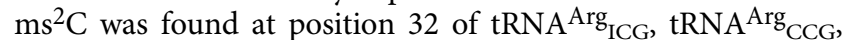
tRNA $^{\mathrm{Arg}}{ }_{\mathrm{UCU}}$ and tRNA ${ }_{\mathrm{GCU}}$. Only $1 \%$ of the $\mathrm{s}^{2} \mathrm{C}$ modified tRNA isoacceptors carry $\mathrm{ms}^{2} \mathrm{C}$ under unstressed growth conditions. The endogenous formation of $\mathrm{ms}^{2} \mathrm{C}$ was not found to be connected to common tRNA modifying enzymes. At this stage we cannot determine whether the endogenous, but low abundant, $\mathrm{ms}^{2} \mathrm{C}$ modification of bacterial tRNA is introduced enzymatically or by direct methylation through, e.g., SAM. For low abundant nucleoside modifications it is often an open question whether they are lesions or functional entities ${ }^{24}$.

Intrigued by the observation that $\mathrm{ms}^{2} \mathrm{C}$ forms naturally in the presence of the methyl donor SAM, we were wondering whether $\mathrm{ms}^{2} \mathrm{C}$ is formed by direct methylation during alkylation stress after MMS exposure. MMS is a direct mono-methylating agent, which is known to methylate RNA nucleosides and DNA nucleosides. From our systematic study, we know that the main damage products of canonical nucleosides are $\mathrm{m}^{1} \mathrm{~A}$ and $\mathrm{m}^{7} \mathrm{G}^{10}$. In the current study, we also focused on the quantities of $\mathrm{ms}^{2} \mathrm{C}$ formed during an $\mathrm{LD}_{50}$ MMS exposure of E. coli. We find 0.1 $\mathrm{m}^{1} \mathrm{~A}$ damage sites per average tRNA and surprisingly $0.05 \mathrm{~ms}^{2} \mathrm{C}$ per average tRNA. At lower MMS doses $(3 \mathrm{mM})$, the number of $\mathrm{m}^{1} \mathrm{~A}$ damage sites is reduced to 0.014 per average tRNA and $0.018 \mathrm{~ms}^{2} \mathrm{C}$ per average tRNA. It is now clear that $\mathrm{ms}^{2} \mathrm{C}$ is an equally prominent damage product as $\mathrm{m}^{1} \mathrm{~A}$ in total tRNA. If one considers that the average tRNA in bacteria is composed of 15 adenosines while only $0.1 \mathrm{~s}^{2} \mathrm{C}$ are found in the average tRNA, our results are rather intriguing. Although adenosine is 150 fold more abundant than $\mathrm{s}^{2} \mathrm{C}$ in total tRNA, the methylation products $\mathrm{m}^{1} \mathrm{~A}$ and $\mathrm{ms}^{2} \mathrm{C}$ are of comparable quantities. From our data, we conclude that $\mathrm{s}^{2} \mathrm{C}$ is an at least equal or even better substrate of direct methylation than adenosine in the tRNA of the bacterium E. coli.
Although the abundance of modified nucleosides is low in comparison to the amount of canonical nucleosides in the total RNA pool, modified nucleosides fulfil a variety of important functions within the cell. The damage of a modified nucleoside will most likely interrupt the modification's function and might be disadvantageous to the organism. We have tested how the methylation of $\mathrm{s}^{2} \mathrm{C}$ influences the translation in vivo. Serine can be translated by $\mathrm{tRNA}^{\mathrm{Ser}}{ }_{\mathrm{GGA}}$ (no $\mathrm{s}^{2} \mathrm{C}$ ) reading the TCC codon or tRNA ${ }_{\text {Ger }}$ reading the AGC or AGU codons. We found that $s f g f p$ with the AGC or AGU codon was less efficiently translated than $s f g f p$ with the TCC codon under MMS stress. This finding indicates that the translation of the AGC and AGT codon is disturbed after MMS stress, potentially due to the presence of $\mathrm{ms}^{2} \mathrm{C}$.

The repair of damaged ribonucleosides might occur by two potential mechanisms. RNA is a transient molecule and constantly transcribed from DNA within the cell. Upon damage, it is possible to remove the damage by controlled degradation of the RNA. Due to the fact that tRNA maturation and modification is energy consuming, the second repair scenario of direct damage repair by, e.g., demethylation, is more attractive. In bacterial RNA, the repair of $\mathrm{m}^{1} \mathrm{~A}$ and $\mathrm{m}^{3} \mathrm{C}$ by oxidative demethylation by the enzyme AlkB has been shown ${ }^{7}$. In our NAIL-MS studies, we use stable isotopes such as carbon-13, nitrogen-15 or sulfur-34 to distinguish RNA that was present during the stress event (here, MMS exposure) and new RNA transcribed during the recovery period. We can thus distinguish repair by RNA degradation and demethylation. With NAIL-MS, we observe AlkB dependent demethylation of $\mathrm{ms}^{2} \mathrm{C}, \mathrm{m}^{3} \mathrm{C}$ and potentially $\mathrm{m}^{1} \mathrm{~A}$.

The AlkB dependent repair of $\mathrm{m}^{3} \mathrm{C}$ had been suggested in previous studies but has never been shown in vivo. Surprisingly, $\mathrm{m}^{1} \mathrm{~A}$ repair was similar in the WT and $\triangle a l k B$ mutant. Only for the $3 \mathrm{mM}$ MMS dose, $3 \mathrm{~h}$ after stress exposure, the WT strain showed less $\mathrm{m}^{1} \mathrm{~A}$ per tRNA compared to the $\triangle a l k B$ strain. This is in accordance with the only other in vivo study, where $\mathrm{m}^{1} \mathrm{~A}$ repair by $\mathrm{AlkB}$ was observed in radioactive tRNA $3 \mathrm{~h}$ after stress at a low dose of alkylating agent ${ }^{23}$.

In unstressed $\triangle a l k B$ bacteria, we did not observe an accumulation of $\mathrm{ms}^{2} \mathrm{C}$ (Supplementary Fig. 21). This is to be expected if one considers the low copy number of $\mathrm{AlkB}$ in unstressed 
wildtype bacteria (1 copy of AlkB in log phase E. coli cells ${ }^{25}$ ). Only after exposure to alkylating agents, alkB is induced and six hours after 3 mM MMS exposure $6000 \mathrm{AlkB}$ copies/cell have been found ${ }^{11}$

Concerning $\mathrm{ms}^{2} \mathrm{C}$ repair, we found an increase of original $\left[{ }^{32} \mathrm{~S}\right]-\mathrm{s}^{2} \mathrm{C}$ in vivo, which reflects direct sulfur demethylation by AlkB. With our sophisticated NAIL-MS approach we could additionally observe an $\mathrm{AlkB}$ independent formation of $\mathrm{s}^{2} \mathrm{C}$ which originated from dethiomethylation of $\mathrm{s}^{2} \mathrm{C}$ to cytidine and subsequent rethiolation. The initial dethiolation step might be enzymatically catalyzed, but due to the electrophilic nature of the $\mathrm{C} 2$ in $\mathrm{ms}^{2} \mathrm{C}$, a direct nucleophilic attack by water is also possible.

So far, $\mathrm{m}^{1} \mathrm{~A}$ was thought to be the main methylation damage product in bacterial RNA and thus to be the main substrate of AlkB. Our data shows that $\mathrm{ms}^{2} \mathrm{C}$ is a methylation damage in bacterial tRNAs of comparable extent after MMS exposure. In addition, AlkB is faster during the repair of $\mathrm{ms}^{2} \mathrm{C}$ damaged tRNAs compared to $\mathrm{m}^{1} \mathrm{~A}$ damaged tRNAs.

Since its discovery, AlkB has been an enzyme full of surprises. In this work, we present the next surprise, which is AlkBs extended substrate repertoire and its preference for the sulfur methylated nucleoside $\mathrm{ms}^{2} \mathrm{C}$.

\section{Methods}

Salts, reagents, and nucleosides. All salts were obtained from Sigma-Aldrich (Munich, Germany) at molecular biology grade unless stated otherwise. The isotopically labeled compounds ${ }^{15} \mathrm{NH}_{4} \mathrm{Cl}\left(>98\right.$ atom \%) and $\left[\mathrm{D}_{3}\right]$-L-methionine (98 atom \%) were obtained from Sigma-Aldrich. Isotopically labeled ${ }^{13} \mathrm{C}_{6}$ - glucose ( $\geq 99$ atom \%) and isotopically labeled $\mathrm{Na}_{2}{ }^{34} \mathrm{SO}_{4}(99.11$ atom \%) were obtained from Eurisotope (Saarbruecken, Germany). All solutions and buffers were made with water from a Millipore device (Milli-Q, Merck, Darmstadt, Germany). The nucleosides adenosine, cytidine, guanosine, uridine, and N2-methylguanosine $\left(\mathrm{m}^{2} \mathrm{G}\right)$ were obtained from Sigma-Aldrich. 1-Methyladenosine $\left(\mathrm{m}^{1} \mathrm{~A}\right)$, 2methyladenosine $\left(\mathrm{m}^{2} \mathrm{~A}\right)$, N3-methylcytidine $\left(\mathrm{m}^{3} \mathrm{C}\right)$, N6-methyladenosine $\left(\mathrm{m}^{6} \mathrm{~A}\right)$, 7-methylguanosine $\left(\mathrm{m}^{7} \mathrm{G}\right), 5$-methylcytidine $\left(\mathrm{m}^{5} \mathrm{C}\right), 5$-methyluridine $\left(\mathrm{m}^{5} \mathrm{U}\right), 2^{\prime}$-Omethylcytidine $(\mathrm{Cm}), 2^{\prime}$-O-methylguanosine $(\mathrm{Gm}), 1$-methylguanosine $\left(\mathrm{m}^{1} \mathrm{G}\right)$, and 3-methyluridine $\left(\mathrm{m}^{3} \mathrm{U}\right)$ were obtained from Carbosynth (Newbury, UK)

Synthesis of 2-methylthiocytidine. Twenty milligrams of $\mathrm{s}^{2} \mathrm{C}$ were stirred in $1 \mathrm{~mL}$ anhydrous ethanol under nitrogen atmosphere.7.4 mg of $\mathrm{NaHCO}_{3}$ and $24 \mu \mathrm{L}$ of methyl iodide were added and the reaction was stirred overnight at room temperature. The clear yellow solution was evaporated and two times purified by silica gel chromatography in dichloromethane with $10 \%$ methanol. The $\mathrm{Rf}$ value (TLC) in DCM/MeOH (10:1) was 0.46 .

${ }^{1} \mathrm{H}$ NMR $\left(400 \mathrm{MHz}, \mathrm{D}_{2} \mathrm{O}\right): \delta=8.39(\mathrm{~d}, \mathrm{~J}=7.7 \mathrm{~Hz}, 1 \mathrm{H}, \mathrm{H}-6), 6.60(\mathrm{~d}, \mathrm{~J}=7.7 \mathrm{~Hz}$, $1 \mathrm{H}, \mathrm{H}-5), 5.98\left(\mathrm{~d}, \mathrm{~J}=3.0 \mathrm{~Hz}, 1 \mathrm{H}, \mathrm{H}-\mathrm{1}^{\prime}\right), 4.38\left(\mathrm{t}, \mathrm{J}=3.4 \mathrm{~Hz}, 1 \mathrm{H}, \mathrm{H}-2^{\prime}\right), 4.23-4.18(\mathrm{~m}$, $\left.2 \mathrm{H}, \mathrm{H}-3^{\prime}, \mathrm{H}-4^{\prime}\right), 3.99$ (d, J = 12.7Hz, 1H, H-5'a), 3.85 (dd, J = 2.7 Hz, $13.4 \mathrm{~Hz}, 1 \mathrm{H}$, $\left.\mathrm{H}-5^{\prime} \mathrm{b}\right), 2.67\left(\mathrm{~s}, 3 \mathrm{H}, \mathrm{CH}_{3}\right) .{ }^{13} \mathrm{C}$ NMR $\left(500 \mathrm{MHz}, \mathrm{D}_{2} \mathrm{O}\right): \delta=166.4(\mathrm{C}-2), 162.1(\mathrm{C}-4)$, 141.5 (C-6), 102.1 (C-5), $92.7\left(\mathrm{C}-1^{\prime}\right), 84.6\left(\mathrm{C}-3^{\prime}\right), 74.9\left(\mathrm{C}-2^{\prime}\right), 68.5\left(\mathrm{C}-4^{\prime}\right), 59.8$ (C$\left.5^{\prime}\right), 14.4(\mathrm{C}-7)$.

E. coli and P. aeruginosa strains. The used E. coli wild-type strain BW25113 and the isogenic knockout strains were purchased from the Keio database ${ }^{26}$. Pseudomonas aeruginosa PA14 was a generous gift of Prof. Peter Dedon. Knockout strains with kanamycin resistance were grown on kanamycin LB agar plates $(50 \mu \mathrm{g} / \mathrm{mL})$. The E. coli strain AG1 (ME5305) transformed with the indicated pCA24N-based vectors was used for gene overexpression and ordered from the ASKA library database ${ }^{27}$. Strains with chloramphenicol resistance were grown in the presence of chloramphenicol $(30 \mu \mathrm{g} / \mathrm{mL})$. All cultures were grown in a shaking incubator at $37^{\circ} \mathrm{C}$ at $250 \mathrm{rpm}$ (Orbit $=10 \mathrm{~mm}$ ). Overnight cultures were grown in $5 \mathrm{~mL}$ of the media used for the respective experiment. The cells were grown starting with an $\mathrm{OD}_{600}$ of $0.1,0.5$ or 1 (as specified in the respective section) and grown until reaching stationary phase $\left(\mathrm{OD}_{600} \sim 4\right)$.

Growth media LB/ M9/ isotope labeled. For LB media, LB Broth (Luria Miller) from Roth (Karlsruhe, Germany) was used. 1.5\% (wt/vol) agar plates were prepared with LB-broth and Agar-Agar (Kobe I from Roth) according to manufacturer's protocol.

M9 minimal medium was used with and without the indicated isotopes. Unlabeled M9 was prepared by mixing a $10 \times \mathrm{M} 9$ stock solution with glucose, $\mathrm{MgCl}_{2}, \mathrm{Na}_{2} \mathrm{SO}_{4}$, and $\mathrm{CaCl}_{2}$ (as detailed below). For unlabeled $10 \times \mathrm{M} 9$ stock solution, $\mathrm{Na}_{2} \mathrm{HPO}_{4}(68 \mathrm{~g} / \mathrm{L}), \mathrm{KH}_{2} \mathrm{PO}_{4}(30 \mathrm{~g} / \mathrm{L}), \mathrm{NaCl}(2.5 \mathrm{~g} / \mathrm{L})$, and $\mathrm{NH}_{4} \mathrm{Cl}(10 \mathrm{~g} / \mathrm{L})$ were mixed and autoclaved. For ${ }^{15} \mathrm{~N}$-labeled $10 \times \mathrm{M} 9$ stock solution, ${ }^{15} \mathrm{NH}_{4} \mathrm{Cl}$ $(10 \mathrm{~g} / \mathrm{L})$ was used. $\mathrm{MgCl}_{2}(0.1 \mathrm{M}), \mathrm{CaCl}_{2}(0.1 \mathrm{M}), \mathrm{Na}_{2} \mathrm{SO}_{4}(0.1 \mathrm{M})$, and $20 \%$ (wt $\left.\%\right)$ glucose were prepared by sterile filtration. A $20 \%$ (wt\%) ${ }^{13} \mathrm{C}_{6}$-labeled glucose solution was prepared for ${ }^{13} \mathrm{C}$-labeled M9 media. For ${ }^{34}$ S-labeled M9 media a $0.1 \mathrm{M}$ $\mathrm{Na}_{2}{ }^{34} \mathrm{SO}_{4}$ solution was prepared. Final M9 media was prepared by mixing, e.g., $500 \mu \mathrm{L}$ M9 stock solution with $100 \mu \mathrm{L}$ glucose, $100 \mu \mathrm{L} \mathrm{MgCl}_{2}, 100 \mu \mathrm{L} \mathrm{Na}_{2} \mathrm{SO}_{4}, 5 \mu \mathrm{L}$ $\mathrm{CaCl}_{2}$ and water to a final volume of $5 \mathrm{~mL}$. For ${ }^{15} \mathrm{~N}$-labeled cultures, the ${ }^{15} \mathrm{~N}-10 \times$ M9 stock solution was used. For ${ }^{13} \mathrm{C}$-labeled cultures, the $20 \%$ (wt $\left.\%\right){ }^{13} \mathrm{C}_{6}$-labeled glucose solution and for ${ }^{34} \mathrm{~S}$-labeled cultures, the $0.1 \mathrm{M} \mathrm{Na}_{2}{ }^{34} \mathrm{SO}_{4}$ solution was used. For $\mathrm{CD}_{3}$-methylome labeling, $200 \mu \mathrm{L} \mathrm{CD}_{3}$-methionine (stock $5 \mathrm{~g} / \mathrm{L}$ ) was added to $5 \mathrm{~mL}$ of culture volume.

E. coli knockout/overexpression strain library. The knockout strains were cultured in $\mathrm{LB}$ or $\mathrm{M} 9$ media, starting from $\mathrm{OD}_{600}=0.5$. After $3 \mathrm{~h}$ the cells were harvested and the RNA was isolated and purified. The overexpression strains were cultured in LB media starting with an $\mathrm{OD}_{600}=0.5$ and an IPTG concentration of $0.1 \mathrm{mM}$. After $1 \mathrm{~h}$ incubation at $37^{\circ} \mathrm{C}$ and $250 \mathrm{rpm}($ Orbit $=10 \mathrm{~mm})$ the IPTG concentration was increased to $1 \mathrm{mM}$ to induce full overexpression. The bacteria were incubated for further $2 \mathrm{~h}$ before the cells were harvested and RNA was isolated and purified

Survival assay. Unlabeled M9 media was used throughout the survival assay. A $5 \mathrm{~mL}$ culture with $\mathrm{OD}_{600} 1.0$ (or 0.1 , respectively) were prepared from an E. coli overnight culture. After $60 \mathrm{~min}$ incubation (30 min with Streptozotocin), $100 \mu \mathrm{L}$ of the culture were diluted $10^{-5}$ or $10^{-6}$ with sterile water. From this dilution $70 \mu \mathrm{L}$ were plated on a prewarmed LB agar plate. The colony number of this plate represents $100 \%$ bacterial survival. MMS (Methyl-methanesulfonate, 99\%) or Streptozotocin (STZ, $10 \mathrm{mM}$ stock solution) was added to the remaining bacteria in defined concentrations. After $60 \mathrm{~min}(30 \mathrm{~min})$ exposure, $100 \mu \mathrm{L}$ of the culture were diluted and plated. The LB plates were incubated at $37^{\circ} \mathrm{C}$ overnight and the colonies counted for determination of the survival at the respective MMS or STZ concentration.

E. coli incubation with Streptozotocin (STZ). From an overnight culture of E. coli strain $\mathrm{BW} 25113$ (WT) the $\mathrm{OD}_{600}$ was brought to 1.0 and the culture was grown for $1 \mathrm{~h}$. To $5 \mathrm{~mL}$ bacterial culture $125 \mu \mathrm{L}$ of a $10 \mathrm{mM} \mathrm{STZ}$ solution was added $(200 \mu \mathrm{M}$ final conc.) and the culture was incubated for $30 \mathrm{~min}$. Afterwards, the bacteria were centrifuged and the resulting pellet was used for RNA isolation and purification.

Cell lysis and tRNA purification. The bacteria culture was centrifuged at $1200 \times g$ for $5 \mathrm{~min}$. The supernatant was discarded and the cell pellet was resuspended in $1 \mathrm{~mL}$ TRI reagent (Sigma-Aldrich) per $5 \mathrm{~mL}$ bacteria culture. The total RNA was isolated according to the supplier's manual. tRNA was purified by size exclusion chromatography (SEC) according to published procedures ${ }^{10}$. The tRNA was resuspended in water $(30 \mu \mathrm{L})$.

Isoacceptor purification. The procedure was adapted from Hauenschild et al. ${ }^{22}$. One microgram of total tRNA was incubated with 100 pmol of the biotinylated DNA probe and purified using Dynabeads T1 (Thermo Fisher Scientific, Waltham, MA, USA) according to the manusfacturer's protocol. For tRNA isoacceptor purification, pre-purified total tRNA was used. The sequences of the biotinylated $2^{\prime}$-deoxyoligonucleotide probes are listed in Supplementary Table 4.

Comparative NAIL-MS. One E. coli culture was grown overnight in an unlabeled M9 medium and another in a ${ }^{13} \mathrm{C}$ labeled M9 medium. From these cultures, a labeled and unlabeled exposure culture with an $\mathrm{OD}_{600}$ of 1.0 and a volume of $5 \mathrm{~mL}$ were prepared. After $60 \mathrm{~min}$ growth, $8.5 \mu \mathrm{L}$ MMS (final conc. $20 \mathrm{mM}$ ) were added to the unlabeled culture and $8.5 \mu \mathrm{L}$ of water to the ${ }^{13} \mathrm{C}$-labeled culture (MOCK). After $60 \mathrm{~min}$ of exposure both cultures were mixed and the RNA was purified immediately. Total tRNA and tRNA isoacceptors were isolated as described above. For validation of the comparative NAIL-MS assay, the experiment was repeated by mixing and co-purifying RNA (total tRNA and tRNA isoacceptors) from an unlabeled MOCK treated culture and a ${ }^{13} \mathrm{C}$-labeled MOCK treated culture.

Methylome discrimination assay. For this assay, $\mathrm{CD}_{3}$-labeled $\mathrm{M} 9$ medium was used at all times. A $5 \mathrm{~mL}$ bacterial solution with an $\mathrm{OD}_{600}$ of 0.1 was prepared from an overnight culture. After 60 min growth, $8.5 \mu \mathrm{L}$ MMS (final conc. $20 \mathrm{mM}$ ) were added. As a control, $8.5 \mu \mathrm{L}$ water was added to a second culture. After $60 \mathrm{~min}$ of exposure, the RNA was isolated and total tRNA purified by SEC.

sfGFP reporter and single-cell fluorescence microscopy. For in vivo quantification of the effects of tRNA modifications after MMS stress on translation, the $E$. coli strains BW25113, BW25113 $\triangle a l k B$ and BW25113 $\Delta t t c A$ were transformed with pBAD24 containing a copy of sfgfp under the control of the arabinose-inducible $\mathrm{P}_{\mathrm{BAD}}$ promoter. To test the effects of different serine codons (AGC, AGT, TCC) the only serine codon of the used sfgfp sequence (corresponds to amino acid position 2) was exchanged by using the respective primers during the cloning process. To enhance the number of serines, the sfgfp sequence was extended at the $5^{\prime}$-end with multiple motifs coding for proline-alanine-serine 
(ASPAAPSASAPSAASAAPSAA)-sequence, modified from previous studies ${ }^{28}$. We used the primers PAS-gfp_for/ PAS-AGT_gfp_for / PAS-TCC_gfp_for plus gfp_rev to introduce different types of codons for serine (AGC, AGT or TCC) in the sfGFP variants extended with the proline-alanine-serine (ASPAAPSASAPSAASAAPSAA)-sequence or respectively gfp_for / AGT_gfp_for / TCC_gfp_for plus gfp_rev to produce the sfGFP variants with different types of codons for serine (AGC, AGT or TCC). The restrictions sites EcoRI and XbaI were used for integration of the sf $f p$ variants into the pBAD24 plasmid.

For each experiment cells of an overnight culture were inoculated into fresh M9 minimal medium supplemented with $0.5 \%$ ( vol/vol) glycerol as a sole carbon source and incubated under vigorous shaking at $37^{\circ} \mathrm{C}$. Cells were grown to mid-log phase, and the culture was divided. One half was stressed by the addition of MMS to final concentrations of 3 and $20 \mathrm{mM}$, respectively, the other half remained untreated. After $1 \mathrm{~h}$ of incubation in presence of MMS the medium was exchanged with fresh, pre-tempered M9 minimal media supplemented with $0.5 \%$ (vol $/ \mathrm{vol}$ ) glycerol and $0.2 \%$ (vol/vol) arabinose to induce sfGFP expression. As a control, cells were cultivated without addition of arabinose. To measure sfGFP fluorescence, cells were fixed on an agarose pad ( $1 \% \mathrm{wt} / \mathrm{vol}$ in phosphate-buffered saline) placed on a microscope slide with coverslip. Micrographs were taken on a Leica microscope DMI 6000B equipped with a Leica DFC 365Fx camera (Andor, 12 bit). sfGFP fluorescence was visualized using an excitation wavelength of $460 \mathrm{~nm}$ and a $512 \mathrm{~nm}$ emission filter with a 75-nm bandwidth. Fluorescence intensities of a minimum of 300 cells per transformant were collected and quantified using Fiji ${ }^{29}$.

Pulse-chase NAIL-MS experiment. A single colony of E. coli BW25113 or E. coli JW2200-KC $(\triangle a l k B)$ was picked and grown in unlabeled M9 medium $(5 \mathrm{~mL})$ overnight. From the first overnight culture, a $50 \mathrm{~mL}$ culture was prepared in unlabeled M9 medium and grown overnight. From the second overnight culture, $120 \mathrm{~mL}$ culture $\left(\mathrm{OD}_{600}\right.$ of 1.0$)$ was prepared in unlabeled M9 medium. After 60 min growth, the first aliquot $(7 \mathrm{~mL})$ was taken for RNA isolation. The remaining culture was split into two flasks of $56.5 \mathrm{~mL}$ each. One was exposed to MMS $(95.7 \mu \mathrm{L}, 20 \mathrm{mM}$ final concentration) the other to water (MOCK) and inverted before both cultures were cultivated for $60 \mathrm{~min}$. An aliquot $(7 \mathrm{~mL})$ was drawn from each culture, and the RNA was isolated. The remaining bacteria were centrifuged $(1200 \times g, 5 \mathrm{~min})$, and the MMS/MOCK-containing supernatants were discarded. The bacteria pellets were washed with ${ }^{15} \mathrm{~N},{ }^{34} \mathrm{~S}$ and $\mathrm{CD}_{3}$-methionine labeled $\mathrm{M} 9$ medium $(5 \mathrm{~mL})$, and each bacterial pellet was suspended in fresh ${ }^{15} \mathrm{~N} /{ }^{34} \mathrm{~S} / \mathrm{CD}_{3} \mathrm{M} 9$ medium $(50 \mathrm{~mL})$. The bacteria were allowed to grow and recover from the MMS/ MOCK treatment. Seven millilitres of each bacterial culture were harvested after 1, $2,3,4$, and $23 \mathrm{~h}$. The RNA was isolated and the tRNA purified by SEC. The experiment was also done with lower volumes and different concentrations of MMS.

SAM and MMS incubation assay in vitro. $4.3 \mu \mathrm{L}$ of a $93 \mu \mathrm{M} \mathrm{s}{ }^{2} \mathrm{C}$ synthetic standard solution $(0.4 \mathrm{nmol})$ were mixed with $0,500,1000,1500$ or 2000 equivalents of SAM (32 mM stock) or MMS ( $20 \mathrm{mM}$ stock) in a final volume of $100 \mu \mathrm{L}$ containing $50 \mathrm{mM} \mathrm{Na} 2 \mathrm{HPO}_{4} / \mathrm{NaH}_{2} \mathrm{PO}_{4}$ buffer ( $\mathrm{pH}$ 7.0). The mixture was incubated at $37^{\circ} \mathrm{C}$ for $60 \mathrm{~min}$ in a shaking heat block. After incubation, $900 \mu \mathrm{L}$ water were added (1:10 dilution) and spiked with SILIS to be analyzed by quantitative LC-MS/MS

AlkB in vitro assay. Five microlitres of purified tRNA $(30 \mathrm{ng} / \mu \mathrm{L})$ from $20 \mathrm{mM}$ MMS exposed E. coli was mixed with $45 \mu \mathrm{L}$ of AlkB. $(45 \mu \mathrm{L}$ AlkB was prepared with $7.5 \mu \mathrm{L} \mathrm{KCl}(100 \mathrm{mM}), 1.5 \mu \mathrm{L}$ freshly mixed sodium $\alpha$-ketoglutarate $(10 \mathrm{mM}), 2.5 \mu \mathrm{L}$ Tris buffer (1 M, pH 7.65), $5 \mu \mathrm{L}$ freshly mixed sodium L-ascorbate $(20 \mathrm{mM}), 1.5 \mu \mathrm{L}$ freshly mixed $\mathrm{Fe}(\mathrm{II})\left(\mathrm{NH}_{4}\right)_{2}\left(\mathrm{SO}_{4}\right)_{2}(10 \mathrm{mM})$ and $1.5 \mu \mathrm{L}$ of AlkB enzyme $(39.1 \mu \mathrm{M}$, Peak Proteins, Cheshire, UK) and water.) The reaction mixture was incubated at $37^{\circ} \mathrm{C}$ for $60 \mathrm{~min}$. After incubation, $500 \mu \mathrm{L}$ of $\mathrm{LiClO}_{4}$ in acetone ( $2 \mathrm{vol} \%$ ) was added for tRNA precipitation and mixed thoroughly. After $10 \mathrm{~min}$ at room temperature, the sample was centrifuged at $5000 \times g$ for $10 \mathrm{~min}$. The RNA pellet was washed with $70 \mathrm{vol} \%$ ethanol and resuspended in $20 \mu \mathrm{L}$ water before digestion for LC-MS/ MS analysis.

tRNA digestion for mass spectrometry. tRNA (100 ng) in aqueous digestion mix $(30 \mu \mathrm{L})$ was digested to single nucleosides by using $0.2 \mathrm{U}$ alkaline phosphatase, $0.02 \mathrm{U}$ phosphodiesterase I (VWR, Radnor, Pennsylvania, USA), and $0.2 \mathrm{U}$ benzonase in Tris $(\mathrm{pH} 8,5 \mathrm{mM})$ and $\mathrm{MgCl}_{2}(1 \mathrm{mM})$ containing buffer. Furthermore, $0.5 \mu \mathrm{g}$ tetrahydrouridine (Merck, Darmstadt, Germany), $1 \mu \mathrm{M}$ butylated hydroxytoluene, and $0.1 \mu \mathrm{g}$ pentostatin were added to avoid deamination and oxidation of the nucleosides ${ }^{30}$. The mixture was incubated for $2 \mathrm{~h}$ at $37^{\circ} \mathrm{C}$ and then filtered through 96-well filter plates (AcroPrep Advance $35010 \mathrm{~K}$ Omega, PALL Corporation, New York, USA) at $3000 \times g$ and $4^{\circ} \mathrm{C}$ for $30 \mathrm{~min} .1 / 10$ Vol. of SILIS (stable isotope labeled internal standard) as prepared in ${ }^{31}$ was added to each filtrate before analysis by QQQ mass spectrometry.

High resolution mass spectrometry. The ribonucleosides were separated using a Dionex Ultimate 3000 HPLC system on an Interchim Uptisphere120-3HDO C18 or a Synergi, $2.5 \mu \mathrm{m}$ Fusion-RP $\mathrm{C}_{18}, 100 \AA ., 100 \times 2 \mathrm{~mm}$ (Phenomenex ${ }^{\circledR}$, Torrance, California, USA). Mobile phase A was $2 \mathrm{mM}$ ammonium acetate and mobile phase
B was $80 \%$ acetonitrile containing $2 \mathrm{mM}$ ammonium acetate. Gradient elution started with $0 \% \mathrm{~B}$ and increased to $12 \% \mathrm{~B}$ after $10 \mathrm{~min}$ and to $80 \%$ after $12 \mathrm{~min}$. After 4 min elution at $80 \% \mathrm{~B}$ and subsequently regeneration of starting conditions to $100 \% \mathrm{~A}$ after $5 \mathrm{~min}$, the column was equilibrated at $100 \% \mathrm{~A}$ for $8 \mathrm{~min}$. The flow rate was $0.2 \mathrm{~mL} / \mathrm{min}$ and the column temperature $30^{\circ} \mathrm{C}$. High-resolution mass spectra of precursor and product ions were recorded by a ThermoFinnigan LTQ Orbitrap XL. The parameters of the mass spectrometer were tuned with a freshly mixed solution of adenosine $(5 \mu \mathrm{M})$. The parameters were sheath gas flow rate, 16 arb; auxiliary gas flow rate, 11 arb; sweep gas flow rate, 4 arb; spray voltage, $5.0 \mathrm{kV}$; capillary temperature, $200^{\circ} \mathrm{C}$; capillary voltage, $20 \mathrm{~V}$, tube lens $65 \mathrm{~V}$.

QQQ mass spectrometry. For quantitative mass spectrometry an Agilent 1290 Infinity II equipped with a diode-array detector (DAD) combined with an Agilent Technologies G6470A Triple Quad system and electrospray ionization (ESI-MS, Agilent Jetstream) was used. Operating parameters: positive-ion mode, skimmer voltage of $15 \mathrm{~V}$, cell accelerator voltage of $5 \mathrm{~V}, \mathrm{~N}_{2}$ gas temperature of $230^{\circ} \mathrm{C}$ and $\mathrm{N}_{2}$ gas flow of $6 \mathrm{~L} / \mathrm{min}$, sheath gas $\left(\mathrm{N}_{2}\right)$ temperature of $400^{\circ} \mathrm{C}$ with a flow of $12 \mathrm{~L} / \mathrm{min}$, capillary voltage of $2500 \mathrm{~V}$, nozzle voltage of $0 \mathrm{~V}$, and nebulizer at $40 \mathrm{psi}$. The instrument was operated in dynamic MRM mode.

For separation a Core-Shell Technology column (Phenomenex, Torrance, CA, USA; Kinetex $1.7 \mu \mathrm{m} \mathrm{EVO} \mathrm{C}_{18}, 100 \AA, 150 \times 2.1 \mathrm{~mm}$ ) at $35^{\circ} \mathrm{C}$ and a flow rate of $0.35 \mathrm{~mL} / \mathrm{min}$ were used in combination with a binary mobile phase of $5 \mathrm{mM}$ $\mathrm{NH}_{4} \mathrm{OAc}$ aqueous buffer $\mathrm{A}$, brought to $\mathrm{pH} 5.6$ with glacial acetic acid $(65 \mu \mathrm{L})$, and an organic buffer B of pure acetonitrile (Roth, LC-MS grade, purity 2.99 .95 ). The gradient started at $100 \%$ solvent A, followed by an increase to $10 \%$ over $10 \mathrm{~min}$. From 10 to $15 \mathrm{~min}$, solvent B was increased to $45 \%$ and was maintained for $3 \mathrm{~min}$ before returning to $10 \%$ solvent $\mathrm{A}$ and a 3 min re-equilibration period.

Calibration. For calibration, synthetic nucleosides were weighed and dissolved in water to a stock concentration of 1-10 mM. Due to an unknown content of water and salts in the synthesized $\mathrm{ms}^{2} \mathrm{C}$ standard, the concentration could not be determined through weighing. Therefore, the concentration of the stock solution was determined by comparison to $\mathrm{s}^{2} \mathrm{C}$ containing isoacceptors after MMS exposure. The calibration solutions range from 0.3 to $500 \mathrm{pmol}$ for each canonical nucleoside and from 0.3 to $500 \mathrm{fmol}$ for each modified nucleoside and were spiked with $10 \%$ SILIS $^{20}$. The sample data were analyzed by the Quantitative and Qualitative MassHunter Software from Agilent. The areas of the MRM signals were integrated for each modification and their isotope derivatives.

The absolute amounts of the modifications were referenced to the absolute amounts of the respective canonical. In the case of the pulse-chase experiment, the different isotopomers were referenced to their respective labeled canonicals, so that original modifications were referenced to original canonicals and new modifications were referenced to new canonicals. See Eqs. (1) and (2) for $\mathrm{s}^{2} \mathrm{C}$ as an example in Supplementary Table 12.

Statistics. All experiments were performed at least three times (biological replicates) to allow student $t$-test analysis. $p$-values of student $t$-test (unpaired, twotailed, equal distribution) were calculated using Excel or Graphpad Prism.

Reporting summary. Further information on research design is available in the Nature Research Reporting Summary linked to this article.

\section{Data availability}

A reporting summary for this Article is available as a Supplementary Information file. The source data underlying Figs. 1c, d, 2a-c, 3a, c, 4b-e, 5b, c and Supplementary Figs. 2a, 5-8, 10-18, 20, 21 as well as Supplementary Table 10 are provided as a Source Data file. All relevant data are available from the corresponding author upon reasonable request.

Received: 5 September 2019; Accepted: 14 November 2019; Published online: 06 December 2019

\section{References}

1. Boccaletto, P. et al. MODOMICS: a database of RNA modification pathways. 2017 update. Nucleic Acids Res. 46, D303-D307 (2018).

2. Rydberg, B. \& Lindahl, T. Nonenzymatic methylation of DNA by the intracellular methyl group donor S-adenosyl-L-methionine is a potentially mutagenic reaction. EMBO J. 1, 211-216 (1982).

3. Taverna, P. \& Sedgwick, B. Generation of an endogenous DNA-methylating agent by nitrosation in Escherichia coli. J. Bacteriol. 178, 5105-5111 (1996).

4. Sedgwick, B. \& Lindahl, T. Recent progress on the Ada response for inducible repair of DNA alkylation damage. Oncogene 21, 8886-8894 (2002).

5. Sedgwick, B. \& Vaughan, P. Widespread adaptive response against environmental methylating agents in microorganisms. Mutat. Res 250, 211-221 (1991). 
6. Wuosmaa, A. M. \& Hager, L. P. Methyl chloride transferase: a carbocation route for biosynthesis of halometabolites. Science 249, 160-162 (1990).

7. Fedeles, B. I., Singh, V., Delaney, J. C., Li, D. \& Essigmann, J. M. The AlkB family of $\mathrm{Fe}$ (II)/alpha-Ketoglutarate-dependent dioxygenases: repairing nucleic acid alkylation damage and beyond. J. Biol. Chem. 290, 20734-20742 (2015).

8. Yi, C. \& He, C. DNA repair by reversal of DNA damage. Cold Spring Harb. Perspect. Biol. 5, a012575 (2013).

9. Cozen, A. E. et al. ARM-seq: AlkB-facilitated RNA methylation sequencing reveals a complex landscape of modified tRNA fragments. Nat. Methods 12, 879-884 (2015).

10. Reichle, V. F., Weber, V. \& Kellner, S. NAIL-MS in E. coli determines the source and fate of methylation in tRNA. Chembiochem 19, 2575-2583 (2018).

11. Vagbo, C. B., Svaasand, E. K., Aas, P. A. \& Krokan, H. E. Methylation damage to RNA induced in vivo in Escherichia coli is repaired by endogenous AlkB as part of the adaptive response. DNA Repair 12, 188-195 (2013).

12. Reichle, V. F. et al. Surpassing limits of static RNA modification analysis with dynamic NAIL-MS. Methods 156, 91-101 (2018).

13. Aas, P. A. et al. Human and bacterial oxidative demethylases repair alkylation damage in both RNA and DNA. Nature 421, 859-863 (2003).

14. Cantara, W. A. et al. Modifications modulate anticodon loop dynamics and codon recognition of E. coli tRNA(Arg1,2). J. Mol. Biol. 416, 579-597 (2012).

15. Jager, G., Leipuviene, R., Pollard, M. G., Qian, Q. \& Bjork, G. R. The conserved Cys-X1-X2-Cys motif present in the TtcA protein is required for the thiolation of cytidine in position 32 of tRNA from Salmonella enterica serovar Typhimurium. J. Bacteriol. 186, 750-757 (2004).

16. Kellner, S. et al. Profiling of RNA modifications by multiplexed stable isotope labelling. Chem. Commun. 50, 3516-3518 (2014).

17. Dal Magro, C. et al. A vastly increased chemical variety of RNA modifications containing a thioacetal structure. Angew. Chem. Int Ed. Engl. 57, 7893-7897 (2018).

18. Carbon, J., David, H. \& Studier, M. H. Thiobases in Escherchia coli transfer RNA: 2-thiocytosine and 5-methylaminomethyl-2-thiouracil. Science 161, 1146-1147 (1968).

19. Ikeuchi, Y. et al. Agmatine-conjugated cytidine in a tRNA anticodon is essential for AUA decoding in archaea. Nat. Chem. Biol. 6, 277-282 (2010).

20. Borland, K. et al. Production and application of stable isotope-labeled internal standards for RNA modification analysis. Genes 10, E26 (2019).

21. Juhling, F. et al. tRNAdb 2009: compilation of tRNA sequences and tRNA genes. Nucleic Acids Res. 37, D159-D162 (2009).

22. Hauenschild, R. et al. The reverse transcription signature of N-1methyladenosine in RNA-Seq is sequence dependent. Nucleic Acids Res. 43, 9950-9964 (2015).

23. Ougland, R. et al. AlkB restores the biological function of mRNA and tRNA inactivated by chemical methylation. Mol. Cell 16, 107-116 (2004).

24. Pfaffeneder, T. et al. Tet oxidizes thymine to 5-hydroxymethyluracil in mouse embryonic stem cell DNA. Nat. Chem. Biol. 10, 574-581 (2014).

25. Schmidt, A. et al. The quantitative and condition-dependent Escherichia coli proteome. Nat. Biotechnol. 34, 104-110 (2016).

26. Baba, T. et al. Construction of Escherichia coli K-12 in-frame, single-gene knockout mutants: the Keio collection. Mol. Syst. Biol. 2, 20060008 (2006).

27. Kitagawa, M. et al. Complete set of ORF clones of Escherichia coli ASKA library (a complete set of E. coli K-12 ORF archive): unique resources for biological research. DNA Res. 12, 291-299 (2005).

28. Schlapschy, M. et al. PASylation: a biological alternative to PEGylation for extending the plasma half-life of pharmaceutically active proteins. Protein Eng. Des. Sel. 26, 489-501 (2013).
29. Schindelin, J. et al. Fiji: an open-source platform for biological-image analysis. Nat. Methods 9, 676-682 (2012)

30. Cai, W. M. et al. A platform for discovery and quantification of modified ribonucleosides in RNA: application to stress-induced reprogramming of tRNA modifications. Methods Enzymol. 560, 29-71 (2015).

31. Kellner, S. et al. Absolute and relative quantification of RNA modifications via biosynthetic isotopomers. Nucleic Acids Res. 42, e142 (2014).

\section{Acknowledgements}

V.R. and S.K. are grateful for funding from the Fonds der chemischen Industrie. The project is financially supported by the Deutsche Forschungsgemeinschaft [Exc114-2 (S.K. and K.J.), KE1943/3-1 (S.K.) and Projektnummer 325871075, SFB 1309 (S.K.)]. Funding for open access publication is provided by the LMU mentoring program (S.K.). V.R. and S.K. thank Thomas Carell and his group for instrument time (QQQ and high-resolution mass spectrometer), infrastructure for synthesis and advice. V.R. and S.K. thank Mark Helm for E. coli overexpression strains.

\section{Author contributions}

V.R., D.P., K.J., and S.K. planned the experiments and wrote the manuscript. V.R., D.P. and V.W. conducted the experiments. V.R., D.P., and V.W. performed data analysis.

\section{Competing interests}

The authors declare no competing interests.

\section{Additional information}

Supplementary information is available for this paper at https://doi.org/10.1038/s41467019-13565-9.

Correspondence and requests for materials should be addressed to S.K.

Peer review information Nature Communications thanks the anonymous reviewers for their contribution to the peer review of this work. Peer reviewer reports are available.

Reprints and permission information is available at http://www.nature.com/reprints

Publisher's note Springer Nature remains neutral with regard to jurisdictional claims in published maps and institutional affiliations.

\begin{abstract}
(c) (i) Open Access This article is licensed under a Creative Commons Attribution 4.0 International License, which permits use, sharing, adaptation, distribution and reproduction in any medium or format, as long as you give appropriate credit to the original author(s) and the source, provide a link to the Creative Commons license, and indicate if changes were made. The images or other third party material in this article are included in the article's Creative Commons license, unless indicated otherwise in a credit line to the material. If material is not included in the article's Creative Commons license and your intended use is not permitted by statutory regulation or exceeds the permitted use, you will need to obtain permission directly from the copyright holder. To view a copy of this license, visit http://creativecommons.org/ licenses/by/4.0/.
\end{abstract}

(c) The Author(s) 2019 